\title{
Low-Income Energy Assistance Programs:
}

A Profile of Need and Policy Options

July 1980

Fuel Oil Marketing Advisory Committee of the U.S. Department of Energy

Economic Regulatory Administration

Office of Petroleum Operations

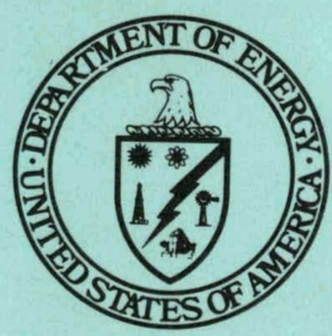




\section{DISCLAIMER}

This report was prepared as an account of work sponsored by an agency of the United States Government. Neither the United States Government nor any agency Thereof, nor any of their employees, makes any warranty, express or implied, or assumes any legal liability or responsibility for the accuracy, completeness, or usefulness of any information, apparatus, product, or process disclosed, or represents that its use would not infringe privately owned rights. Reference herein to any specific commercial product, process, or service by trade name, trademark, manufacturer, or otherwise does not necessarily constitute or imply its endorsement, recommendation, or favoring by the United States Government or any agency thereof. The views and opinions of authors expressed herein do not necessarily state or reflect those of the United States Government or any agency thereof. 


\section{DISCLAIMER}

Portions of this document may be illegible in electronic image products. Images are produced from the best available original document. 
Avallable from:

National Technical Information Service (NTIS)

U.S. Department of Commerce

5285 Port Royal Road

5285 Port Royal Road 22161

Price:

$\begin{array}{ll}\text { Printed Copy: } & \$ 8.00 \\ \text { Microfiche: } & \$ 4.00\end{array}$ 


\section{Low-Income Energy Assistance Programs:}

\section{A Profile of Need and Policy Options}

\section{master}

July 1980

Fuel Oil Marketing Advisory Committee of the U.S. Department of Energy

Economic Regulatory Administration Office of Petroleum Operations

Washington, D.C. 20461
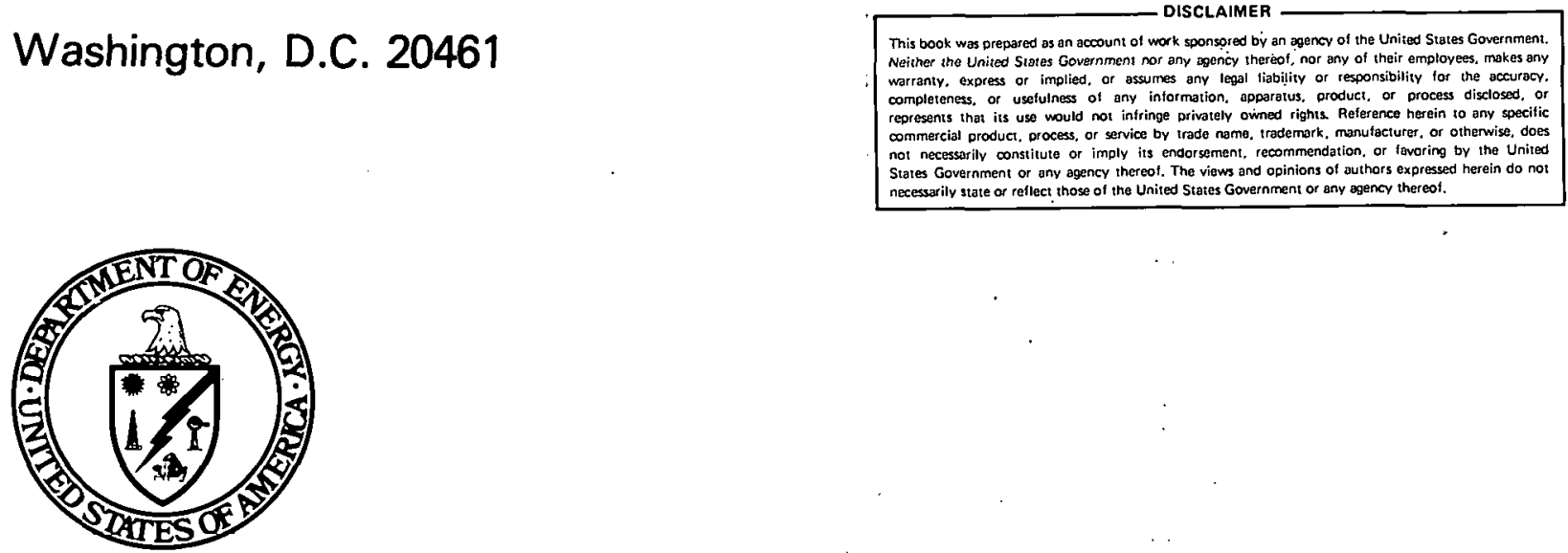

$q^{5}$ 
July 3,1980

MEMORANDUM FOR HAZEL ROLLINS

ADMINISTRATOR

ECONOMIC REGULATORY ADMINISTRATION

DEPARTMENT OF ENERGY

FROM :

JOHN BUCKLEY, CHAIRMAN

FUEL OIL MARKETING ADVISOG COMMITTEE DEPARTMENT OF ENERGY

ANTHONY J. MAGGIORE, JR.

CHAIRMAN, SUBCOMMITTEE ON

ASSISTANCE PROGRAMS

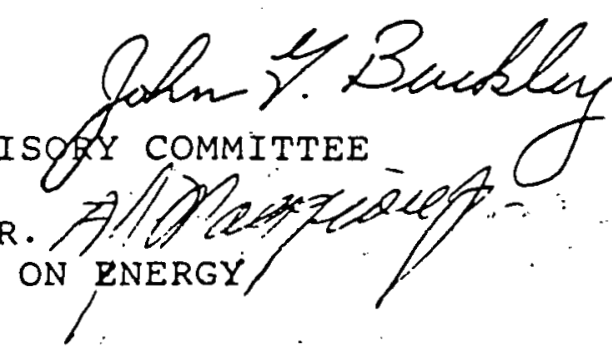

SUBJECT :

LOW-INCOME ENERGY ASSISTANGE UPDATED REPORT

Attached for your review is a copy of the Fuel oil Marketing Advisory Committee (FOMAC) report entitled "Low-Income Energy Assistance Programs: A Profile of Need and Policy Options." This report updates FOMAC's earlier report on this subject dated July $26,1979$.

Last year's report had a major impact on national energy assistance programs and created an impetus for the Administration's Energy Crisis Assistance and Special Energy Allowances Programs.

since last year, when low-income families were spending 24.5 percent of their income on total energy costs, continuing rising prices have driven the percentage of income spent on total energy to alarmingly higher levels. We project that in 1980, low-income families will spend as much as 35.7 percent of their incomes on total energy needs.

FOMAC has prepared this updated report in order to address this alarming trend and its impact on low-income people. In the report, we have:

- documented the increasingly desperate economic condition of the poor due to higher energy prices, showing that the poor will have lost $\$ 14$ billion in purchasing power between 1978 and 1980;

- examined carefully the levels of funding which FOMAC feels are necessary to alleviate some of the burden borne by the poor, showing that a program of at least $\$ 3.5$ billion is necessary to offset this year's loss of purchasing power; 
- proposed a comprehensive program design for delivering energy assistance to the poor which we hope will serve as a model for improvements in the Administration's program;

- expanded the program design developed by FOMAC last year to include a major emphasis on conservation, through weatherization and alternative sources of energy, as a positive mechanism for shielding the poor from rising energy prices.

We hope this report will contribute to a more effective national program for 1980-81 and for future years. We hope, as well, that you will ensure that the report receives widespread distribution and that it reaches the appropriate government agencies and jolicyudkers. 
Important contributions to this report have been made by a number of individuals who have, given generously of their time and expertise. We owe special thanks to FOMAC members Ellen Berman, Executive Director of the Consumer Energy Council of America and Henry Lee of the Harvard University Center for Energy and Environmental Policy. We thank Julia Nanay of Northeast Petroleum Corporation and Carol Werner, National Consumer Law Center. From the Department of Energy, Economic Regulatory Administration, we thank Hazel R. Rollins, Paul T. Burke, T. Wendell Butler, Richard Morrow and Susan Cauderlier; Office of Consumer Affairs, Dr. Eric E. West. From the Department of Health and Human Services, Office of the Assistant Secretary for Planning and Evaluation, we thank John Todd and Alan Cohen. From the Community Services Administration, we thank Lee Foley, Office of the Director and Richard Saul, Energy Programs Division. From the United States Congress, we thank Meg. Power, Office of Senator Jacob Javits; Pat Markey, Office of Senator Harrison Williams; and Joel Eisenberg, New England Economic Research office.

Finally, this report would not have been possible without the work of two individuals to whom we are deeply grateful: Dr. Mark. Cooper, Researoh Dircctor of the Consumer Energy Council of America and George Gerharz, Research Director, Community Relations/Social Development Commission of Milwaukee County. 
Chapter

Page

I. Executive Summary. • . . . . . . . . . . 1

II. Needs Assessment . . . . . . . . . . . 7

III. Government Response. . . . . . . . . . . 24

IV. FOMAC Model. . . . . . . . . . . . 28

V. Comments on the Current

. 1979-80 Energy Assistance Program. . . . . 39

VI. Comments on the Proposed 1980-81

Home Energy Assistance Program. . . . . . 46

VII. Projected Cost of 1980-81

Energy Assistance Program. . . . . . . 50

VIII. Conservation . . . . . . . . . . . 52

IX. Program Financing . . . . . . . . . 65

\section{Appendix A}

Summary of Various Energy Assistance Legislative Proposals Submitted to the U.S. House of Representatives and U.S. Senate

\section{Appendix B}

Bibliography

Appendix C

Listing of the Members of the Fuel Oil Marketing Advisory Committee of the U.S. Department of Energy 


\section{LIST OF TABLES}

Page

I. Estimated National Average Household

Expenditures for Total Energy Costs:

Low-Income/Median-Income, 1.978-80.

II. Estimated National Average Household.

Expenditures for Household Energy Costs:

Low-Income/Median-Income, 1978-80............... 10

III. Consumer Price Index Item Difference in

Annual Average $1978-79 \ldots \ldots \ldots \ldots \ldots \ldots \ldots \ldots \ldots \ldots \ldots \ldots$

IV. Differential in Consumption and Expenditures

for Electricity and Natural Gas Between

Low-Income Households and all U.S. Households, 1975.... 20

v. Comparison of FOMAC and HHS Program Elements.........48

vi. Existing Energy-Related Characteristics by 1977

Family Income (winter $1978-79) \ldots \ldots \ldots \ldots \ldots \ldots \ldots \ldots$

VII. Conservation Efforts Undertaken in 1978 by 1977

Family Income.............................. 54

vIII. The Benefite of Conservation................... 59 


\section{EXECUTIVE SUMMARY}

The purpose of this second report of the Fuel Oil Marketing Advisory Committee (FOMAC), of the Department of Energy is twofold: to update information on the energy needs of low-income persons and governmental response to such needs; and to emphasize the need for energy conservation programs which may alleviate the enormous financial burden placed on low-income people by $r$ ising energy prices.

While continuing to emphasize a national program of energy assistance utilizing an income indexing/vendor line of credit approach. FOMAC has sought to develop further and refine its initial energy conservation recommendations. With energy prices rapidly increasing, the necessity of a comprehensive energy conservation program to protect the health and safety of low-income households and preserve our Nation's energy supplies is even more evident.

Since FOMAC issued its initial report and recommendations a year ago (July, 1979), rising energy costs have had an even greater negative impact on the 16.2 million poor and near poor households (nearly 40 million persons) it proposed to assist.

The 1978 data indicated that, nationally, low-income households were spending 17.88 of their income on household energy. Projections for 1979 and 1980 indicate that during 1980 , the poor, 
nationally, will be spending, on the average, at least 218 of their income directly on household energy, while energy costs in certain regions of the country will exceed $308^{\circ}$ of the income of poor households.

Overall, the updated needs assessment document finds that the poors

1. will expend at least 358 of their income directly on energy and will spend at least $21 \%$ of their income on household energy;

2. will still continue to pay nearly 4 times mure the percentage of their income on household energy than the average American household;

3. suffered a loss in average total income in real terms since 1972, making the acquisition of adequate energy for this group more difficult;

4. will lose over $\$ 6$ billion in purchasing power in 1980 due to increases in energy costs;

5. have experienced, in certain regions of the country, a particulariy harsh and diuplupuilionate burden in paying for energy;

6. have less ability to offiset increased energy costs through product substitution in the marketplace than for any other necessity utilized by poor households;

7. will use less than $50 z$ of the total energy consumed by the average American household and. 258 less household energy:

8. will continue, by necessity, to occupy low quality, energy inefficient housing stock that further penalizes them in their effort to cut energy costs; and

9. lack financial resources to implement significant additional conservation improvements.

Governmental concern regarding these problems has heightened since FOMAC issued its first report in 1979. Congress appropriated 
\$1.6 billion for the 1979-1980 fuel assistance program and has enacted into law the Home Energy Assistance Act of 1980. That Act authorizes grants to states for assistance to eligible lowincome households to offset $r$ ising costs of home energy. In addition, a variety of bills have been introduced in both houses of Congress to establish a permanent program to alleviate the burdens imposed by $r$ ising energy costs and to promote residential conservation.

Congress has also stipulated that 258 of the recently enacted Windfall Profits Tax, approximately $\$ 56.8$ billion, should be utilized for low-income assistance over the next 10 years and has authorized $\$ 3.1$ billion for energy assistance in the calendar year beginning October 1, 1980. The House of Representatives is currently reviewing appropriations for the 1980-81 fiscal and program year and the senate will consider the issue after the House takes action. Hopefully, a decision on funding for the 1980-81 program will be reached this summer.

After careful review of various program designs, FOMAC continues to support the income indexing/vendor line of credit approach originally proposed as retaining its fundamental validity. This design would provide assistance to eligible households based on:

- Energy Needed - heating/cooling needs would be based on size of dwelling and heating/cooling degree days; 
- Cost of Fuel - in terms of energy needed, cost would be calculated on the basis of price of fuel to provide needed heating and cooling;

- Percentage of Income - the method of providing assistance requires that households be responsible for a portion of their heating/ cooling expenses on the basis of income.

The FOMAC design operates through a vendor line of credit, assuring that the benefits are utilized for household energy and places responsibilities on the vendor for delivery and recordkeeping. With variations, the FOMAC design can be used to assist households whose energy costs are included in their rent.

The FOMAC design would clearly serve to offset some of the design flaws of this year's Federal energy assistance program in four ways :

1. Assistance wuld be more proportional to houschold energy needy und abilily to pay.

2. Assistance would be more readily avallable to all the poor, especially the elderly and working poor not enrolled in public assistance programs.

3. The national, local, and individual allocations of assistance would be more clearly tied to heating/ cooling needs versus poverty status.alone.

4. Assistance provided to low-income households would have to be utilized for fuel bills.

On May 30, 1980, the U.S. Department of Health and Human Services (HHS) issued interim final regulations setting forth the requirements for states seeking allotments under the Home Energy Assistance Act of 1980. These regulations have incorporated some of the 
major features of the FOMAC proposed program design as well as recommendations contained in the FOMAC report issued in 1979. In addition, the HHS regulations also attempt to resolve many of the program design problems characteristic of the 1979-80 Energy Assistance Program.

The cost of implementing the FOMAC design nationally would, according to our estimates, range from $\$ 3.5$ to $\$ 4.6$ billion for the 1980-81 winter heating season. This figure is significantly more than the $\$ 1.6-\$ 2.2$ billion budget figures currently being discussed in the Congress.

For example, under the income eligibility guidelines for the 1980-81 Home Energy Assistance Program approximately 20.7 million households may be eligible for assistance. If $75 \%$ of such households participated and received an average of $\$ 200$ per household, the total budget needed for 1980-81 would be $\$ 3.1$ billion, excluding administrative costs.

In view of continually rising energy costs, FOMAC has further developed its recommendations for a comprehensive energy conservation program for low-income households.

Conservation will not only reduce annual increases for energy assistance expenditures, but will also produce conservation energy for the Nation. The cornerstone of such conservation programs 
must be weatherization coupled with consumer education and the use of appropriate forms of alternative energy. Clearly the costs of conservation efforts will be paid back in terms of savings to the individual low-income household as well as to the Nation.

Since the publication of the 1979 FOMAC Report, the needs of lowincome persons have continued to increase because of the high rates of inflation and the current recession. Fuel prices have escalated rapidly. At this time in history, the establishment of an equitable, permanent and standardized national program of energy assistance is critical. At present, however, no agreement on a permanent program design has been reached. The FOMAC design, and the principles on which it is based, can serve as the basis for this national program.

Meeting the ongoing energy needs of the poor will require a coherent national policy which consists of a program to aid the poor in paying their energy bills as well as a program to aid the poor in their efforts to conserve energy.

This report seeks to promote such policies. 
II. NEEDS ASSESSMENT

A. Introduction: The cost of Home Energy Use

Relative price stability in energy existed in the United States until the early 1970's. Historically, Americans have paid little by world standards for their energy and supplies have been assumed to be inexhaustible. However, beginning in 1972-73, abrupt changes in international and national economic and governmental policies caused energy prices to increase explosively, with crude oil prices nearly quadrupling between 1972 and 1978 and doubling again in 1979 .

Between 1972 and 1.979, the overall Consumer Price Index (CPI), measuring the price of all goods and services in the economy, increased more than 748 , while fuel oil prices increased more than 2108 in the same period.I/ And because the cost of energy is itselfalarge factor in the CPI, the differential between energy price movements and price increases in non-energy goods and services is, in fact, even more dramatic than this comparison suggests.

The Nation's 16.2 million low-income households (U.S. Census Bureau data, $1979--$ all households below 1258 of poverty and elderly households below 1508 of poverty) have been hit hard by this increase in energy costs -- far, far harder than had

I/ U.S. Department of Labor, Bureau of Labor Statistics, 1980 
energy cost increases simply matched the rate of inflation. Further, the increase in energy cost has taken, proportionally, a much larger bite out of the low-income family's budget than it has out of the budget of middle-income families.

The total direct energy expenditures (including transportation/ gasoline costs) by low-income households were, on a national average, $24.5 \%$ of their income in 1978 (see Table I). Based on conservative projections, such expenditures will exceed 358 in calendar year 1980. By comparison, while energy prices are also impacting on median-income households, their direct expenditures for all energy were slightly over 108 of their income in 1978 and will exceed 138 of their income in 1980. Thus, low-income households will expend nearly three times more (35.78 vs. 13.28 ) the percentage of their annual income on all energy than medianincome households.

The bulk of energy expenditures for low-income households will be spent on home energy costs (fuels and utilities, excluding transportation/gasoline costs). In 1978, home energy expenditures were, on a national average, $\$ 604$ per household; such expenditures represented 17.88 of the income of low-income households (see Table II). By 1980, it is estimated that such expenditures will rise to $\$ 809$ and represent 21.88 of the income of lowincome households. 
TABLE I

ESTIMATED NATIONAL AVERAGE HOUSEHOLD

EXPENDITURES FOR TOTAL ENERGY COSTS:

LOW-INCOME/MEDIAN-INCOME

$1978-1980$

LOW-INCOME

\begin{tabular}{lcc}
\hline Avg. Energy & Avg. Median & Spent \\
Expenditure & Income & On Energy
\end{tabular}

1978

832

$\underline{1979} \underline{4} / \quad 1049$

1322

$19805 /$

Conservative

Estimate

3703

35.7
TYPICAL MEDIAN

\begin{tabular}{lcc}
\hline Avg. Energy & Avg. Median & \& Spent \\
Expenditure & Income & On Energy
\end{tabular}

$16781 /$

$17,640 \underline{3} /$

9.5

2116

18,825

11.2

2668

20,196

13.2

40.196

(1)

1/ Estimates are for household energy expenditures including transportation/gasoline costs. It should be noted that these figures represent national averages and do not reflect regional differences. Estimates in this table are based on the Energy Information Agency CHRDS data base, DOE.

2/ Bureau of the Census, Current Population Reports, "Consumer Income" Series P-60, No. 119, March 1979.

3/ Bureau of the Census, Current Population Report, March 1980.

4/ 1979 estimates based on an actual annual increase of 26.18 in total energy costs (1979-1980 Consumer Price Index) and on an estimate of 78 average increase in income for median-income households and a 4.358 increase in income for low-income households.

5/ 1980 conservative estimate based on the assumption of a continued average rate of increase in energy prices of 26.18 with a 78 increase in income for median-income households, and a 4.358 increase in income for low-income households. 
TABLE II

ESTIMATED NATIONAL AVERAGE HOUSEHOLD EXPENDITURES FOR HOUSEHOLD ENERGY COSTS: LOW-INCOME/MEDIAN INCOME

LOW-INCOME

\begin{tabular}{lcc}
\hline Avg. Energy & Avg. Median & Spent \\
Expenditure & Income & On Energy
\end{tabular}

\begin{tabular}{lcc}
\multicolumn{4}{c}{ TYPICAL MEDIAN } \\
\hline Avg. Energy & Avg. Median & \& Spent \\
Expenditure & Income & On Energy
\end{tabular}

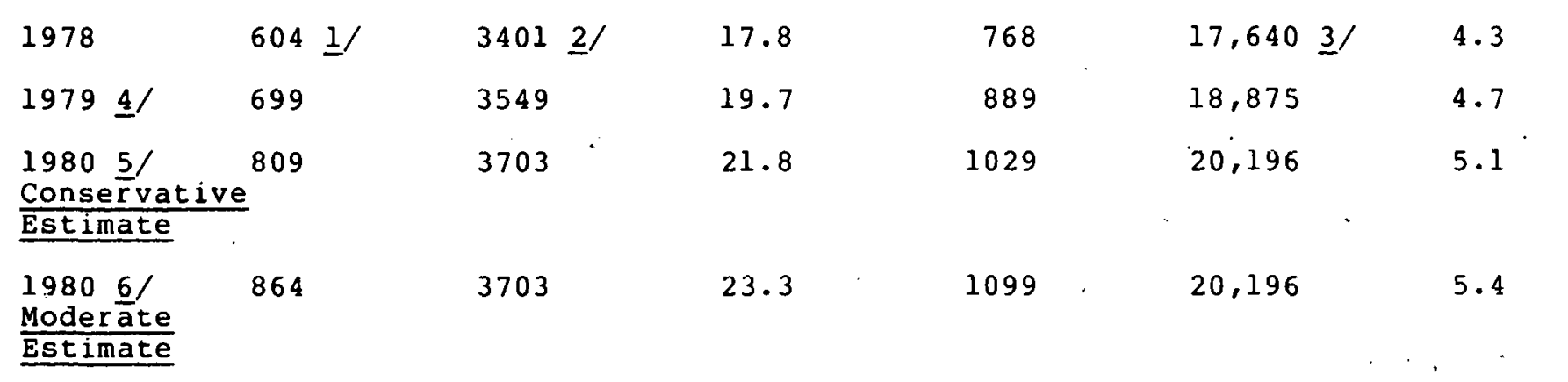

1/ Estimates include only household expenditures; transportation/yasuline expenditures are not included. It should be noted that these figures represent national averages and do not reflect regional differences. Estimates in this table are based on projections of unpublished data received from the Bureau of Labor Statistics. Similar projections based on data from Urban Institute's Survey of llouseholds (1976), the Energy Information Agency CHRDS series and data contained in the Consumer Expenditure Survey (1972-73), produced comparable results, when updated, with the range of difference being plus or minus $\$ 30$.

'2/ Bureau of the Census Current Population Reports, "Consumer Income" Series P-60, No. 119, March 1979.

3/ Bureau of Census, Current populatlun Report, March 1900.

4/ 1999 estimates based on an actual annual incrcase of 15.78 in household energy costs (1979-80 Consumer Price Index) and on a 78 average increase in income for median-income households and a 4.358 increase in income for low-income houscholds.

5/ 1980 estimates assume the same increase of 15.78 in ald househola energy costs with a 78 average increase in income for median-income households and a 4.358 increase in income for low-income households.

6/ 1980 estimates are based on an increase in household energy costs of 23.68 ; an income increase of 78 for median-income households; 4.358 increase for low-income households. The deregulation of oil and natural gas, the increased costs of imported natural gas and oil and the increased costs of electricity account for the greater costs of energy. 
For median-income households, the cost of household energy will rise from $\$ 768$ to $\$ 1,029$, but such an increase will represent less than a 18 increase in terms of percentage of income spent on energy (from 4.58 to 5.18 ).

In brief, in 1980 , the percentage of income that low-income households will spend on home energy, on the average, will be four times that of median-income households. Energy costs of the poor will exceed $\$ 800$ per household on an annual basis and the poor will utilize 21.88 of their income directly on household energy.

On the average, actual consumption of home energy by low-income households is $25 \%$ less than that of median-income households.2/ It is difficult to project further reductions in household energy consumption without a comprehensive home weatherization program which at this time is not available to most low-income households. Such households lack the financial, and other resources required to implement the weatherization of their homes. In terms of their current scope and funding, federal weatherization programs will not serve significant numbers of households in 1980 or in the near future.

2/ U. S. Department of Energy, National Interim Energy Consumption Survey, Single-Family Households: Fuel Oil Inventories and Expenditures, Washington, D.C., December 1979. See also, Washington Center for Metropolitan Studies, National Survey of Household Energy Use, Washington, D.C., 1975; Energy Policy Project of the Ford Foundation, A Time to Choose, Cambridge, Massachusetts, 1974 . 
In addition, it should be noted that the above cost projections are very conservative. The most commonly utilized household fuels -- piped gas and home heating oil -- have led the way in price increases in 1979-1980 (see Table III). With crude oil decontrol, phased deregulation of natural gas, and rising costs of importing both oil and natural gas, dramatic price increases will continue to occur.

With present high levels of expenditures, continual price increases and few opportunities for comprehensive home conservation, low-income households have limited ability to reduce one of their least discretionary expenditures: household energy to maintain life, health and safety.

The immediate effect of $r$ ising energy costs has been a loss of income to purchase the other necessilies of life -- sheltcr, food, and health care -- the costs of which have also risen sharply. The continued escalation of home energy costs has had a dramatic impact on the general purchasing power of the poor. In 1978 and 1979, low-income households lost approximately $\$ 4$ billion each year in purchasing power. In 1980, the poor will lose $\$ 6$ billion in purchasing power. Thus, for the period 1978-80 nearly $\$ 14$ billion has been taken from the pockets of the most economically disadvantaged segment of our society due solely to increased energy prices. 
TABLE III

CONSUMER PRICE INDEX ITEMS

DIFFERENCE IN ANNUAL AVERAGE: 1978 - 1979

(Urban Wage Earners and Clerical Workers)

78 Average

Al1 Energy

All Household Fuels

Electricity

Piped Gas

Fuel oil

Gasoline

Overall Index
220.3

247.4

203.7

262.5

296.9

191.8

195.3
79 Average

277.7

286.3

219.4

303.9

417.3

263.6

217.7
Percentage Increase

$$
26.1
$$

15.7

7.7

15.8

40.6

35.3

11.5

SOURCE: U.S. Department of Labor, Bureau of Labor statistics. 
In the long run, continuing increases in energy prices not remedied by a national program of energy assistance and by major efforts at energy conservation, could jeopardize the health and safety of the poor and elderly of our Nation.

\section{B. The Particular Energy Hardship of the Poor}

It is apparent that the low-income households in America pay a far higher proportion of their total annual income fur energy than do median-income households. However, it must be understood that these aggregate factors represent only a national average. The poor in various regions of the country where climate conditions are more severe than average.-- and energy costs are higher -- face a still greater problem. For example, it was estimated in 1978 that it costs New England residents $38.8 \%$ more than the national average to supply adequate energy to their homes. $\underline{3} /$ This points to the magnitude of the disparities in need and the resulting numerous cases of extreme hardship Lhat lie behind the aggrcgate average figures.

Structural factors inherent in the energy delivery system combine to make the energy burden on the poor yet higher. First among these factors is the operation of the energy pricing structure. Utilizing inverted pricing schedules, with declining rates at nigher usage levels, utility companies charge higher unit prices

3/ Eunice and George Grier, The New England Energy Consumer, Grier Partnership, Bethesda, Maryland, January 1979. p. 28. 
for those consumers using smaller amounts of energy. As lowincome households consume less energy than the average household they are particularly affected by inverted pricing schedules. Due to higher per-unit prices paid by low-income households, the difference in total amounts spent annually for energy between low-income households and all households was less than the difference in energy consumption.

The same inverted pricing structure applies to fuel oil. For economic reasons most companies reduce the cost per gallon of fuel for large orders and increase the cost per gallon for smaller orders. Further, those using fuel oil are confronted with additional problems. In general, low-income consumers have smaller storage capacities and, with rare exception, do not have adequate resources to purchase larger orders even if they have larger storage capacities. $\underline{4}$ / In addition, the credit and delivery practices of fuel oil dealers inadvertently penalize the poor. Because of credit practices, low-income persons are normally prevented from using credit or budget payments to pay for the fuel. They generally do not have a high enough credit rating to warrant these deferred approaches. As a result, low-income consumers are forced to pay "cash on delivery" (COD) for fuel oil. The COD system is particularly onerous for the poor and near-poor.

4/ Testimony, Anthony Maggiore, DOE Fuel Oil Evidentiary Hearing, 1978 
For most households, fuel expenditures occur in a relatively short period of a few months. Those on credit or budget plans can spread fuel costs over a much longer time period than the lowincome household which is forced to pay cash on delivery. Further, since low-income households do not generally have credit plans, they are, for the most part, denied automatic refills. They cannot have their tank filled when oil is needed -- only when they have sufficient cash for immediate payment. In addition, it must be noted that, in many cases, persons who are not on credit or budget payments are forced to pay certain "surcharges" for such items as delivery at certain times and to certain places. 5 / As a result of these factors, during winter months, energy bills can equal or be greater than the total monthly income of low-income households.

The low-income family is further penalized by the qualley of its housing stock, which is generally older, in worse repair, and more poorly insulated than those houses inhabited by median-income hnuseholds (see Table VI). In northern climates, this results in the need to use more fuel. to maintain a certain temperature than in well-insulated homes. Thus, the low-income family's home is likely to be even less well heated than is suggested by the fact that the poor consume less energy per household than does the average American family.

5/ Ibid. 
In the south, the substandard quality of the poor's housing stock also manifests itself in higher energy costs. In cheaply designed dwelling units -- particularly in mobile homes which are prevalent in southern states -- air conditioning is a necessity. Temperatures in non-air conditioned low-income southern homes present severe health hazards to the occupants - many of whom are elder1y, suffering from respiratory or heart ailments made wor'se "by" increases in home temperature. In Dallas, Texas, in July 1978 , over twenty people died from heat prostration. They were all elderly, poor and lacked air conditioning. A similar and more severe situation occurred again in Dallas, Texas, during the months of June and July 1980 .

\section{Evoliomic Constraints in the Marketplacel Why the Poor Have Lost Ground Since 1972}

There are three overriding economic factors in the marketplace which explain the exceptional inability of the poor to adjust to higher energy costs. These are:

- The average real income of the poor household has actually decreased since 1972 ;

- Reduction in costs through additional conservation is extremely difficult for poor households; and

- Substitutability is lower for household energy needs than for most other goods or services in the economy. 
1. Decrease in Real Income

According to the most recent national figures, the disposable income of the poor and near-poor has not kept pace with the overall CPI. The major public assistance programs have not made up the inflationary gap for those low-income households receiving aid. All items in the CPI rose approximalely 638 rrull 1973-79. The average monthly unemployment insurance benefits rose only 52 during the same period; further, since unemployment insurance is an unstable and a limited form of income, this probably had less impact on real income maintenance than is generally assumed: 6/ The more steady income maintenance programs did not come close to matching inflation during this period. Between 1973 and 1979 the weighted average of the maximum amount paid to an AFDC family of four rose 358. I/ Therefore, real AFDC benefits to families with no other income has fallen 288. From 1974-79 all items in the CPI rose 47.28 . During that same period, the average monthly supplemental security income (SSI) benefit payments rose an average of 258. Thus, a situation has existed from 1973 until the present, in which the major income transfer mechanisms have not maintanined the real purchasing power of those receiving aid. Clearly, the elderly and those households on fixed incomes are most seriously affected.

6/ U.S. Department of Labor, June 1980 .

I/ U.S. Department of HHS, June 1980 . 


\section{Barriers to Additional Conservation}

On a national aggregate level, reduction in household energy consumption through conservation has been somewhat successful in helping median-income people live with higher energy prices. Northeast fuel oil dealers estimate that the response by homeowners to the first wave of price increases in 1973-1974 showed a 158 average reduction in the use of home heating oil. 8 / However, this tactic for reducing the amount of income spent on energy has not and will not work well for the poor.

Simply put, evidence is ample that the poor generally are already conserving as much as they are able -- more, in fact, than could be regarded as healthy. As Table IV shows, low-income households use 548 less electricity and 24.18 less natural gas than the average U.S. household. Thus, the average low-income family subsists on lower amounts of energy than the average American and has already conserved to the point of endangering health.

Conservation methods involving the upgrading of the quality of the housing unit are, by and large, out of the financial reach of the low-income family. While many poor would stand to gain through conservation resulting from the upgrading of their homes -- as the dwellings tend to be highly inefficient

8/ Transcript, Case \#DEH-0058, DOE Office of Hearings and Appeals, August 1978. 
TABLE IV

DIFFERENTIAL IN CONSUMPTION AND EXPENDITURES FOR ELECTRICITY AND NATURAL GAS BETWEEN LOW-INCOME HOUSEHOLDS

AND ALL U.S. HOUSEHOLDS, 1975

\begin{tabular}{lccc}
\hline & $\begin{array}{c}\text { Low-Income } \\
\text { Households }\end{array}$ & $\begin{array}{c}\text { All U.S. } \\
\text { Households }\end{array}$ & $\begin{array}{c}\text { Difference } \\
\text { (Percent) }\end{array}$ \\
\hline $\begin{array}{c}\text { Electricty* } \\
\begin{array}{c}\text { Average annual Btus per } \\
\text { household (million) }\end{array}\end{array}$ & 60.6 & 94.2 & 55.48 \\
$\begin{array}{c}\text { Average annual cost per } \\
\text { household (dollars) }\end{array}$ & $\$ 188.00$ & $\$ 273.10$ & 47.98 \\
$\begin{array}{c}\text { Average price per million } \\
\text { Btus }\end{array}$ & $\$ 3.10$ & $\$ 2.95$ & \\
$\begin{array}{c}\text { Natural Gas } \\
\begin{array}{c}\text { Average annual Btus per } \\
\text { household (million) }\end{array}\end{array}$ & 109.8 & 136.3 & 24.18 \\
$\begin{array}{c}\text { Average annual cost per } \\
\text { household (dollars) }\end{array}$ & $\$ 182.30$ & $\$ 224.60$ & 2.3 .28 \\
$\begin{array}{c}\text { Average price per million } \\
\text { Btus }\end{array}$ & $\$ 1.66$ & $\$ 1.65$ & \\
\hline
\end{tabular}

SOURCE: Washington Center for Metropolitan Studies, National Survey of Household Energy Use, 1975.

* The Public Utility Regulatory Act of the National Energy Act states that utility companies must consider, among other things, the applicability of a prohibition against declining block rates which favor larger users by pricing successive blocks of electricity at lower per-unit prices, and further, lifeline rates for essential needs. 
in per-Btu utilization of energy -- the cash is simply not available to them.

Unlike most middle and upper-income families, the cash flow of the low-income family is not flexible enough to meet crisis situations. The large cash outlays needed for weatherization would be available only by foregoing expenditures on such pressing necessities as food or clothing. Due to low credit ratings, or in some cases because their homes are in allegedly "redlined" neighborhoods, low-income households' access to "home improvement" loans is severely limited. Further, since a high proportion of low-income families rent, rather than own their homes, there is little incentive to make improvements in which they would have no equity. To compound the problem, landlords renting units to low-income families often keep their units in poor repair and are reluctant to make improvements. Clearly, low-income families are already financially constrained to be thrifty in their energy use. This thriftiness is an illustration of the fact that low-income families have little or no scope for further reduction of energy use.

\section{Limited Substitutability of Fuels}

Substitutability is the dynamic economic factor which sets energy-caused income problems apart from other price and inflation-related income problems affecting the poor. 
Substitution is the avenue open to a consumer to offset the effect of an increase in price for a given good or service in the marketplace. If a good increases in price to the point that consumers cannot afford sufficient quantitites of that good, they will substitute for it a different, cheaper good of the same general type. In most necessity items, substitution is a practical possibility. In food and clothing there are many alternative goods which consumers may substitute for a single good that they can no longer afford. For instance, there has been a dramatic $r$ ise in the purchase by consumers of non-name brand food products in the last six years of spiralling prices.

But in energy, substitution, particularly. in the short term, is a practical impossibility. Current options available to the greatest number of low-income people for provision of household energy are limited to principally three: oil, gas, and electricity.

Capital costs of substitution among the three options are so prohibitively high that substitution has been proven to take place only over the very long-term and only with changes in the housing stock itself. Thus, low-income consumers do not have the practical option of substituting a different form of energy for their present source as their bills climb even higher. (Clearly, efforts should be made to utilize alternative sources of energy where practical -- such as solar, etc.) 
Thus, energy, of all goods and services consumed by low-income households, presents a unique threat to the poor's well-being. They are in a worse overall position to fight high energy prices than they were before the beginning of the oil price spiral in 1972. They are incapable, generally, of significantly reducing their costs through reductions in consumption. And they have no other available option to continued consumption -- there is no practical substitution possible that would provide cheaper energy sources. The unique nature of this hardship demands direct action to meet the goals of the Carter Administration's first comprehensive energy plan -- National Energy Plan I. (NEP I) -- which stated a commitment to alleviate the problems of low-income consumers.

It is incumbent upon the government to institute a permanent plan of energy assistance, as well as a major conservation program, to ease the hardship caused to the poor by high energy prices. 


\section{GOVERNMENT RESPONSE}

As noted in the FOMAC Report issued in July 1979, the fifth guiding principle of NEP I was that the U.S. must solve its energy problem in a manner that is "equitable to all regions, sectors, and income groups." Specifically, the White House stated that:

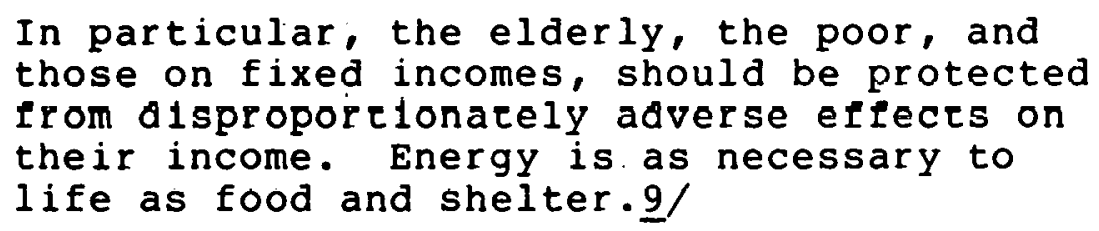

During this period, there has been continued and increasing governmental recognition that low-income households face an energy dilemma of an order of magnitude greater than that faced by most American households. Initial government concern was demonstrated by the Community Services Administration (CSA) in 1973-74 through pilot project funding of a weatherization program in the state of Maine and energy crisis intervention programs in wisconsin, Colorado, and Pennsylvania. In 1975 Congress appropriated funds to CSA for energy conservation services to low-income households, the major focus of which was for the provision of weatherization services. Currently the weatherization program has an authorized funding level of $\$ 200$ million for fiscal year 1980 and is administered by the Department of Energy. In 1977, 1978, and 1979, Congress

9/ The National. Energy Plan, Executive Office of the President, Energy Policy and Planning, April 29, 1977, p. 29. 
expressed its concern through authorizing funds for special Crisis Intervention and Energy Assistance Programs implemented through CSA. Such programs have been helpful but not adequate.

During the spring of 1979, FOMAC issued a draft report entitled "Low-Income Energy Assistance: A Profile of Need and Policy Options." On April 10, 1979, the U.S. Department of Energy and FOMAC sponsored a forum in Washington, D.C. in order to obtain public comment on the draft document. United states Senators and Representatives, national, state, and local government officials, public utility representatives, trade associations, business leaders, community action agencies, and consumer groups provided comments. Such comments were incorporated into a final document and published by FOMAC during the summer of 1979.

On June 4, 1979, Senator Jacob Javits (R-N.Y.) submitted legislation to the U.S. Senate proposing the establishment of a Low-Income Energy Assistance Program (S-1270), the Basic Fuel Assistance Act of 1979.

At least twenty additional members of Congress also submitted legislation to minimize the impact of $r$ ising energy prices on the incomes of low-income people. (See Appendix A) 
During the summer of 1979, President Carter proposed legislation to establish a $\$ 1.6$ billion Low-Income Energy Assistance Program.

Such legislation was approved by Congress during the fall of 1979. The program was administered by the Department of Health and Human Services and the Community Services Administration for the winter of 1979-80.

The need for a long term permanent assistance program had been perceived by members of Congress as well as by the President. As a result of OPEC's oil price increases, the domestic decontrol of crude oil, the subsequent efforts of national and local community groups and organizations to seek a program of assistance for low-income households, and the publication of the original FOMAC report, Senator Harrison Williams (D-N.J.), Chairman of the U.S. Senate Committee on Labor and Human Resources, proposed legislation for a "Home Energy Assistance Act" (S-1724) providing for the establishment of a long-term permanent assistance program. The U.S. Senate favorably considered S-1724 and incorporated the legislation into HR-3919, the Crude Oil Windfall Profits Tax Act of 1980 .

In addition, as part of the second National Energy Plan, President Carter also recommended that a portion of the Windfall profits Tax be utilized for Low-Income Energy Assistance. The President's 
recommendations were discussed at length by the U.S. House-Senate Conference Committee on the windfall profits Tax during the months of January and. February, 1980, and approved by the Conference Committee in February 1980. The Committee agreed that $\$ 3.115$ billion be appropriated for 1980-1981 utilizing Senator Williams' legislative and programmatic design (S-1724).

During March 1980, the House of Representatives approved the House-Senate Conference Committee recommendations. Shortly thereafter, the senate also approved the Committee's recommendations.

Thus, during the period since the publication of the final FOMAC Report in July 1979 ;

1. a $\$ 1.6$ billion program has been implemented for 1979-80;

2. a House-Senate Conference Committee has authorized a $\$ 3.1$ billion program for 1980-81 in the crude oil Windfall Profits Tax Act;

3. the President has proposed a $\$ 2.2$ billion program for 1980-81.

4. the House and Senate will soon decide the level of fiscal appropriations for 1980-81; 10/

5. legislation for a permanent, long-term program is now in progress.

10/ It should be noted that state and local governments have funded a variety of energy assistance programs during the past several years. Such funding has ranged from the provision of assistance only to the elderly and handicapped to assistance to the general low-income population. (See "Energy Assistance Programs and Pricing Policies in the Fifty States to Benefit Elderly, Disabled, or Low-Income Households"; prepared for the Ohio Energy Credits Advisory Committee, Representative Dennis E. Eckart, Chairman, 1979 ; The Institute of Urban Studies, College of Urban Affairs, Cleveland State University, Cleveland, Ohio, 1979.) 
IV. FOMAC MODEL

Given the need for energy assistance and existing governmental concern, the Fuel Oil Marketing Advisory Committee again proposes its design as a model to provide such assistance.

This design is based on some basic principles: 1) equity, 2) promotion of conservation, 3) avoidance of crisis, 4) efficiency of administration, and 5) ability to pay related to need. It offers assistance in relation to need for energy, cost of energy, and ability to pay. Finally, it assures that all the poor, both those who pay directly for their uwn eneryy costs and those whose heating costs are included in their rent, will receive assistance. Below we describe the principles of the design, its basic structure, and its ability to assist all poor with their energy costs.

\section{A. Frogram Criteria and Principles}

Policy judgments as well as fiscal considerations concerning the nature and extent of program coverage were required in order to establish the principles and criteria of an ongoing program of energy assistance.

After lengthy discussion, the following criteria, by which a variety of program options could be judged, were developed bY FOMAC. 
1. Equity

Benefits should vary directly with need. The subsidy should take into consideration climate, type of fuel, household size and household income. The program should include the concepts of vertical and horizontal equity, i.e., benefits should be distributed on the basis of need both within specific income groups and across different income groups. For example, horizontal equity should result in equal treatment of low-income urban and rural participants, of owners and renters, of persons and households receiving public assistance as well as those not receiving such assistance.

2. Conservation

The provision of benefits should seek directly to encourage the conservation of energy.

3. Provision of Energy Assistance Prior to Severe Crisis

Benefits should be provided in a form that reduces initial client payments, minimizes fuel "crisis" and removes financial burdens from vendors, i.e., "frontend assistance," should be available.

4. Efficiency of Administration

Within the requirements of adequate fiscal controls, program integrity, and responsiveness to clients, administrative costs should be held to a minimum while helping the broadest range of eligible persons.

5. Adequacy

The program design should offer benefits which are proportionate to need and costs. The program should also have the flexibility to be responsive to price differentials and changes in the market.

FOMAC examined several possible designs for a low-income

Energy Assistance Program. Two aspects of any possible design were appraised:

1. The type of program which could satisfy objectives $1,2,3$, and 5 above. 
2. The delivery system for the program which, when implemented, would best satisfy objective 4 above.

Utilizing the above criteria, a variety of program options were considered by FOMAC. (See FOMAC Final Report, Appendix A, U.S. Department of Energy, July, 1979.)

B. FOMAC Design

After a review of alternative program options, FOMAC recommends an income indexing/vendor line of credit approach to provide assistance to low-income persons. FOMAC feels that a program based on needed energy and costs for such energy, less an acceptable percentage of energy expenditures which would be provided by the household, could meet the needs of low-income persons in the most equitable fashion. Elements of the FOMAC design follow:

\section{Assistance Formula}

Assistance to a low-inrome household for a given heating or cooling season would be provided to each eligible household on the basis of a simple formula:

- Amount of assistaice woula be based un rieeded energy times cost of energy minus percent of household income.

- Needed energy would be based on the average amount required to heat or cool a residence of a given size, e.g. 1200 gallons of oil;

- Cost of energy would be prevailing price of energy, e.g., $\$ 1.00$ a gallon. 
- A percentage of income, e.g., 10z, would be deducted from the amount which results from multiplying the units of energy needed times the cost of such energy.

The amount of assistance. would be based on needed energy and the cost of such energy. Regional differences would be taken into account in the formula through the inclusion of degree days in determining needed energy and regional costs of various types of energy. Those households in regions which had higher degree days for heating or cooling and had higher prices for energy would receive proportionately more assistance.

The "percentage of income" criterion could take two distinct forms:

- A standard "percentage of income" could be fixed. An eligible household would receive assistance for energy costs which exceeded a certain fixed percentage of income. For example, if a household had an annual income of $\$ 5,000$, it would receive assistance for needed energy costs which exceeded $\$ 500$ (10\% of the household income). For reasons of equity and ease of administration, FOMAC favored this approach.

- However, a sliding "percentage of income" scale could be utilized to increase the amount of assistance to those households with the lowest incomes. 
For example, a household earning $\$ 3,000$ a year would perhaps only be expected to spend 38 of its income on home energy in order to qualify for the assistance program, while the minimum home energy expenditure of a family earning $\$ 7,000 \mathrm{might}$ be set at 118 of income for qualification. With a sliding "percentage of income" scale, assistance would vary inversely with income and thus provide greater assistance to eligible households with lower incomes than the fixed percentage approach.

In either case, for eligible households with equivalent energy needs, those households with the lowest income would receive more assistance than those with higher incomes.

The income-indexing system is best equipped to satisfy FOMAC's belief that both eligibility and the amount of assistance should be derived from energy needs and income level. Income indexing ties these two parameters together more closely than any other available program option examined by FOMAC and best meets program criteria stated above.

\section{Subsidy Disbursement}

The delivery system for the subsidy that FOMAC believes best satisfies criteria 4 is the vendor line of credit with credit flowing through the individual's 
primary energy suppliers. In this system, once program eligibility is determined and a client selects his/her vendor(s), actual payment of the subsidy is a matter between the selected vendor and the Government. Administrative costs are greatly reduced by this system compared to one which must process payments to each individual recipient on a regular basis. Further, for the dealer, costs are reduced as cash tlow problems are minimized. The vendor is not constrained in peak season purchasing decisions by a delay in Government reimbursement. Rather, the vendor is provided a predetermined amount of payment for such energy delivered against which bills sent to the recipient are reduced.

Several options exist for the disbursement of the subsidy:

a. The line of credit could be established in such a way that a monthly subsidy would be made to vendor(s) chosen by the client. The subsidy amount would be in proportion to energy usage in each month in the heating/cooling season.

b. The line of credit could be provided to the vendors on a quarterly or an annual basis. The drawdown rate would be determined by the client's usage and the amount by which bills have been reduced through the guaranteed government subsidy.

c. The line of credit system may be implemented through a tax reduction approach whereby the vendor would deduct the authorized subsidy, once services are provided, from taxes due the Federal Government. If the reimbursement is more than the tax liability, the Internal Revenue would make a "negative tax" payment to the vendor. This approach may simplify the federal administation of an energy assistance prograin for most households, vendors, and the Government. Fiscal and tax procedures would need to be established, however, that minimize potential cash flow problems for small vendors. 
Generally, regardless of which variation of subsidy disbursement is utilized, there is an increased likelihood that delivery practices for low-income households will be regularized in such a way that costs for all parties concerned will be reduced. Indeed, an incentive may exist for the vendor to encourage low-income households to standardize their purchasing and payment practices because of the attractiveness of possible cost savings.

In these ways the low-income household may find itself, for the first time, able to take advantage of financing practices usually available to most other Americans.

In addition to recommending the vendor line of credit approach, FOMAC recommends that those vendors who participate in the program be required to abide by a termination policy and procedure which should be detailed in the program legislation and guidelines established for this assistance program..

C. Coverage of Households in Which Energy Costs are Not Paid Directly By the Owner/Renter

The vendor line of credit would operate in its simplist form in those households, either rented or owner-occupied, in which the occupant has direct responsibility for his/her heating bills. 
In such cases, the line of credit would simply be established with the principle vendor(s) of home heating or utility services.

However, the FOMAC proposal also calls for providing assistance to households whose heating/utility bills are included in their rent. FOMAC realized that special provisions must be made for these approximately 4 million low-income houscholds whose fuel and/or utility costs are included in their rental payment.

Such renters are not responsible for direct payment of energy bills -- rather, the property owner includes energy costs in the rent and then pays the energy bill directly. This category of renter would be bypassed by an energy-assistance delivery system which provides assistance directly through the individual's principal fuel supplier. Thus, a method had to be developed to include eligible renters in the energy assistance program.

A variety of alternatives were considered to assist renters whose energy costs were included in their rent. Cash payments were rejected as being too difficult to monitor and not tied directly to energy costs. Provision of fuel stamps in lieu of a subsidy was determined to be too cumbersome administratively. (See FOMAC Report, DOE, July 1979.)

\section{Voucher system}

The use of vouchers to be applied as part of the rent and to be redeemed by the landlord at the landlord's 
energy supplier appeared to be the best approach to assist renters whose energy costs were included in their rent. On the basis of needed energy, each household would be allocated a certain amount in fuel vouchers. These vouchers would be submitted along with the remainder of the rent due for given periods. The landlord would receive the voucher in lieu of part of the rent payment. The landlord would then redeem these vouchers with the enerqy supplier.11/

2. Landlord's Energy Supplier

Another alternative, having three steps, would also be possible:

a. The renter establishes an account at the landlord's energy supplier;

b. The amount of subsidy would be taken directly from the bill which the vendur provides the landlord;

c. The renter would pay the difference between the total rent and the amount provided by the subsidy.

In this way, front-end assistance would be provided for the entire program and the payment mechanism would be constant. However, this approach would be administratively complex.

11/ A variety of voucher systems could be established. The renter could have a voucher redeemable at a particular vendor. General vouchers could be used which the renter would sign and redeem at any fuel vendor. 
In either of the above approaches, the renter would receive assistance. The landlord would use the voucher for reimbursement of energy expenses or have energy bills reduced by the vendor. The vendor would be able to assist low-income renters with basically the same program design used for eligible households who pay their own energy expenses directly. In both cascs, there would be assurance that the subsidy payment did in fact go to provide energy assistance to the tenant.

\section{Individual Metering}

While attempting to provide assistance to those households which do not pay their own energy bills, FOMAC also recognizes the importance of individual metering as a means of fostering conservation through personal accountability for utility costs. Evidence is accumulating which indicates that personal responsibility for utility bills is an incentive for energy savings and that, particularly with regard to electricity usage, individual metering generally results in substantial reduction in consumption. (See Alternative Metering Practices: Implications for Conservation in Multi-Family Residences, DOE, July 1979.) 
FOMAC, therefore, recommends that, where feasible, individual metering be installed in those situations where it is likely to result in reduced energy consumption and is cost effective. Such a recommendation is made, however, with the recognition of three important caveats:

1. That individual metering should not be implemented in a manner that will significantly incroase the unit coet of cncrgy to the consumer;

2. That the cost of installation be subsidized through Federal and state energy conservation programs; and

3. That appropriate energy conservation measures be implemented prior to or as soon as possible after such metering. 


\section{COMMENTS ON THE CURRENT 1979-80 ENERGY ASS ISTANCE PROGRAM}

\section{A. Introduction}

The Fuel Oil Marketing Advisory Committee has consistently maintained that energy assistance for low-income households should be specifically tied to needed energy times the cost of such energy minus an acceptable percentage of household income spent on such energy. FOMAC has further maintained that such assistance should be delivered in a consistent and uniform manner to all low-income households.

After careful review it has become clear to FOMAC that the Federal Energy Assistance Program (EAP) designed by Congress and HHS's predecessor, the Department of Health, Education and Welfare (HEW), and implemented by states through a Block Grant approach for the winter of 1979-80, was not an energy assistance program but rather an income transfer program. The program was not "energy-sensitive" in that it did not relate directly to current federal energy conservation (weatherization) programs and did not utilize financial assistance formulas based on energy needed and the price of such energy. Because of the design and funding of the 1979-80 program, the following inequities emerged: 
1. The bulk of assistance was provided to that portion of the low-income population receiving some form of public assistance, rather than the total eligible population.

2. The distributional system for aid was inadequate and duplicative.

3. The amount of aid was not sufficient to meet the needs of the low-income population.

4. The financial allocation did not apportion aid on the basis of energy needs and costs.

\section{The Target Population}

The current year's energy assistance program clearly did not reach the entire low-income population. Rather it focused principally on the public assistance population (SSI, AFDC and, in some cases, Food stamp recipient populations). The overall result of such a design was to make assistance readily accessible to less than 508 of the income eligible population. It should be noted that analyses of the U.S. Census Bureau and of HHS data indicate that less than 408 of all households at 1258 of poverty receive AFDC and SSI.

While not negating the energy needs of the public assistance population, or in any way suggesting that this population should not receive energy assistance, FOMAC has taken a position that energy assistance should be available to all eligible lowincome people regardless of public assistance status. 


\section{Distributional System}

Such general availability is not possible without an adequate administrative system. The distributional system utilized during the current year's program was flawed in the following manner :

- It reached principally the public assistance program population.

- It did not tie assistance clearly to energy bills or conservation programs.

- It resulted in unnecessary and/or duplicative payments to individuals and households.

The program distributed checks and/or vouchers to persons enrolled in public assistance programs. Such individuals received the bulk of available assistance. Other low-income households, representing 50-60\% of the low-income population, generally did not have easy access to the program.

When distributing assistance, checks, in many instances, were given to individual households for designated amounts of assistance. The checks, in most cases, did not specify or require that they be used for energy aid. While FOMAC recognizes that most low-income households have needs which exceed their incomes, the purpose of an energy assistance program is to alleviate, specifically, energy needs of low-income people and not to meet their general needs. 
The 1979-80 program has reinforced FOMAC'S recommendation for a single national program tied directly to needed energy, cost of such energy, and conservation (weatherization) programs.

\section{The Amount of Assistance Per Household}

The importance of increasing the amount of assistance per house- hold above the level proposed by the Administration can be seen in a number of different ways. To begin with, the justification for the program was based on the assertion that: "Between 1978 and 1981, the poor will spend a total of $\$ 10$ billion more for energy than they would have in the absence of decontrol and the OPEC increase."12/

FOMAC has shown above that, due to skyrocketing fuel prices, this estimate is entrely too low. FuMAC conservatively estimates that, over this period, low-income households will lose at least $\$ 14$ billion in purchasing power due to increases in household fuel costs alone. These are losses in purchasing power over and above the rate of inflation in non-fuel items. One may quibble over exactly how many dollars are lost to OPEC, to decontrol, or to other factors, but to the poor the net result is the same -- a crushing loss of income that threatens

12 U.S. Department of Health, Education, and Welfare (HEW), Memo: President Carter's Proposal for Low-Income Energy Assistance, Washington, D.C.., September 12, 1979. 
their very survival. There is an order of magnitude difference between the original estimates of energy costs and actual costs that requires an increase in the allotment per household.

The Administration is cognizant of the importance of the rate of inflation, having argued that "it would be desirable to base grants, in part, on the increase in energy costs faced by residents of a state."13/ FOMAC believes that both because the original estimates were too low and because of the rapidity with which inflation in energy prices erodes the purchasing power of the poor, the allotments must at least be scaled upward to keep pace with inflation in energy costs.

\section{Financial Allocation Formula}

FOMAC continues to believe that its formula is best suited for targeting aid to those areas where it is most needed. Since escalating energy prices have been the cause of the exceptional loss of purchasing power suffered by the poor, FOMAC believes that the allocation formula should fully reflect the impact of price. Formulas which fail to take account of both the price of energy and the amount of energy needed do not address the underlying problems confronting low-income households. Overall, the financial allocation formula utilized in the 1979-80 
program did not apportion aid on the basis of energy needed and the cost of such energy. Due to time constraints and other factors, only size of low-income population, degree days and increases in states home heating expenditures from 1978-79 (not actual costs) were utilized as elements in the formula.

Because of the formula for the regional distribution of funds for energy assistance in the 1979-80 program, it was not possible to provide individuals and states within certain regions amounts of assistance proportionate to energy needs. With an inadequate amount of funds, states were not able, generally, to provide to all eligible households assistance proportionate to energy needs on a consistent basis (although it should be mentioned that certain states did, to some extent, attempt to rectify inadequacies by providing more assistance to households with higher priced fuels).

Overall, the 1979-80 program did not meet the FOMAC recommended program criteria referred to earlier in this document, i.e. equity, conservation, adequacy, etc.

\section{Other Comments}

It should be noted that the $1979-80$ program was passed by Congress just prior to the onset of the winter. heating season. Therefore, adequate time to plan for implementation 
of the program was, generally, not available. The program was also hampered by multiple financial distributional formulas and several program components targeted to specific populations, i.e., SSI component. In spite of the somewhat complex program design, time constraints, and a rapidly approaching winter, overall program implementation did occur and was a significant improvement in reaching larger numbers of the eligible population than previous programs. The 1979-80 program funds allocated by Congress were $\$ 1.6$ billion -- or $\$ 1.4$ billion more than the Federal low-income energy assistance effort for the 1978-79 winter heating season. In light of this dramatic increase in funds to serve low-income households and in spite of late Congressional action, the 19\%9-80 program was implemented comparatively well and represented a significant milestone in establishing the need for a Federal low-income energy assistance program. 
VI. COMMENTS ON THE PROPOSED 1980-81 HOME ENERGY ASSISTANCE PROGRAM

As indicated earlier, on May 30,1980 , HHS issued interim final regulations setting forth the requirements for states seeking allotments under the Home Energy Assistance Act of 1980. 14/ The HHS regulations provide for the opportunity to incorporate into state plans several significant elements of the FOMAC program design (see Table V). Among these elements are:

- provision of additional benefits to those households with lower incomes and higher priced fuels;

- assurance that both those households who pay directly for home energy cost and those households which pay indirectly through sheltered cost are equally assisted;

- utilization of a vendor line of credit;

- encouragement of coordination with existing energy conservation programs.

However, fundamental differences remain between FOMAC's approach and that of the program proposed for 1980-81. These differences involve the basic conception of the program and the principles by which it is organized.

1. FOMAC recommends a national program implemented through the states, rather than a state Block Grant program.

2. The 1980-81 HHS regulations embody an income transfer approach, rather than an energy assistance/ conservation approach.

14/ Low-Income Energy Assistance Program, U.S. Department of Health and Human Services, Federal Register, Vol. 45, No. 106, May 30,1980 . 
The underlying problem is a national energy problem; the response should be a national energy assistance program. In order to effectively address the problems confronting lowincome households indicated in this report, a single, uniform, comprehensive program of energy financial assistance and conservation needs to be established. Such a program would insure equitable benefits for all low-income households.

The above stated goal can only be achieved through the legislative process. 
TABLE V

COMPARISON OF FOMAC AND HHS PROGRAM ELEMENTS

FOMAC PROGRAM ELEMENTS

Equity of Benefits

Benefits should vary with need. The subsidy should take into consideration climate, type of fuel, household size, and income. The program chould include the concept of vertical and horizontal equity. (See p. 29)

\section{Conservation}

The provision of benefits should seek directly to encourage the conservation of energy.

The FOMAC recommended financial assistance formula includes a conservation incentive and a percentage of income expenditure by the household. The program should be coordinated and integrated with conservation-weatherization programs.

Provision of Energy Assistance Prior to Severe Crisis

Benefits should be provided in a form that reduces initial client payment, minimizes fuel "crises", etc., (i.e., vendor line of credit should be available).
HHS INTERIM FINAL REGULATIONS FOR THE HOME ENERGY ASSISTANCE PROGRAM FOR 1980-81

Amount of assistance per household should take into account energy needed and the cost of such energy.

The regulations provide for income-indexing based on need. Low-income household owners and renters shall receive equal treatment.

HHS regulations do not incorporate a conservation incentive into the formula for the subsidy payment. HHS regulations do request that states assure that there will be, to the maximum extent possible, referral of individuals to and coordination with existing federal, state and local weatherization and conservation efforts.

The regulations provide for the utilization of vendor $l$ ine of credit. 
TABLE V (Cont'd.)

FOMAC PROGRAM ELEMENTS

Efficiency of Administration

Within the requirements of adequate fiscal controls, proyrall integrity, and responsiveness to clients, administrative cost should be held to a minimum while helping the broadest range of eligible persons.

\section{Adequacy of Benefits}

The program design should offer benefits which are proportionate to need and cost.
HHS INTERIM FINAL REGULATIONS FOR THE HOME ENERGY ASSISTANCE PROGRAM FOR 1980-8I
HHS regulations provide

that the amount of. federal funds the state may use tor administration may not exceed 58 of the cost of carrying out the program. The state must also match the federal funds for administration equally with state funds.

HHS regulations provide that the lowest income households must receive priority and the highest level of assistance must be given to households with the lowest income and the highest energy costs in relation to income. 
VII. PROJECTED COST OF 1980-81

ENERGY ASSISTANCE PROGRAM

In its previous report, FOMAC, utilizing 1978 price figures, estimated that the total cost for energy assistance for lowincome households for 1979-80 would be approximately $\$ 3$ billion if assistance were to be provided for home heating costs (primary fuel only) alone. It total home energy expenses (primary fucl costs plus utilities) were included, the cost of the pruyrail approximated $\$ 4.3$ b111ion.

However, as the original report indicated, it seems reasonable to assume a participation rate of 758 -- i.e., 758 of the eligible population would participate in the program. Based on this participation rate, the cost for the program was determined to be $\$ 2.3$ billion for household heating costs and $\$ 3.2$ billion for all home energy costs.

As indicated in chapter II of this report, energy prices have increased sharply since 1978. For example, the average price per therm of natural gas has increased from 23.6 cents in January 1978 to 34.3 cents in January 1980; the average price per gallon of fuel oil has $r$ isen from 49.2 cents per gallon in January 1978 to 96 cents per gallon in January 1980.

Utilizing present prices and carrying out a state by state analysis by fuel types, the cost for providing assistance to low-income households in the 1980-81 winter heating season 
according to the FOMAC design would be approximately $\$ 4.6$ billion for home heating costs while the cost for providing assistance for total home energy costs would approach $\$ 6.8$ billion at 1008 participation level.

Assuming a 758 participation rate, assistance for home heating costs alone would reach approximately $\$ 3.45$ billion, while assistance for total household energy costs would reach nearly $\$ 5.1$ billion.

The above figures are derived from the data formula, as adjusted, stated in the FOMAC Report published by DOE In July 1979. 
VIII. CONSERVATION

\section{A. The Need for an Expanded Conservation Program}

The 1979 FOMAC report called for a systematic approach to the energy problems and needs of low-income persons. Specifically, it recommended the integration of conservation services with the provision of assistance in paying for needed energy.

As energy prices continue to rise, the need tor conservation becomes even more acute. A number of basic realities must be acknowledged if a long term solution to the energy needs of the poor is to be found:

1. The residential structures of low-income people tend to be in poorer condition and less energy efficient than those of higher-income families. As a recent national housing survey shows, basic energy conserving features are more likely to be absent in the housing of the poor and near poor (see Table VI).

2. This lack of energy efficiency results in annual fuel bills substantially higher than they should be.

3. In terms of simple conservation measures such as thermostat set-backs, caulking, and weatherstripping, the poor have already conserved as much as possible. Yet, they lack the necessary funds to invest in additional conservation such as weatherization. and use of alternative energy sources, which would result in greater energy savings. A recent DOE survey of conservation behavior shows that the poor are just as likely as average income households to take cost-free conservation measures (such as shutting off rooms; see Table VII). However, as the cost of conservation measures increase (such as adding insulation) the poor are less likely than average income households to implement such measures.

4. To date, there has been little or no coordination between energy assistance programs, the weatherization programs, and the federal low-income housing programs. Furthermore, 
TABLE VI

EXISTING ENERGY-RELATED CHARACTERISTICS BY 1977 FAMILY INCOME I/ (Winter 1978-79)

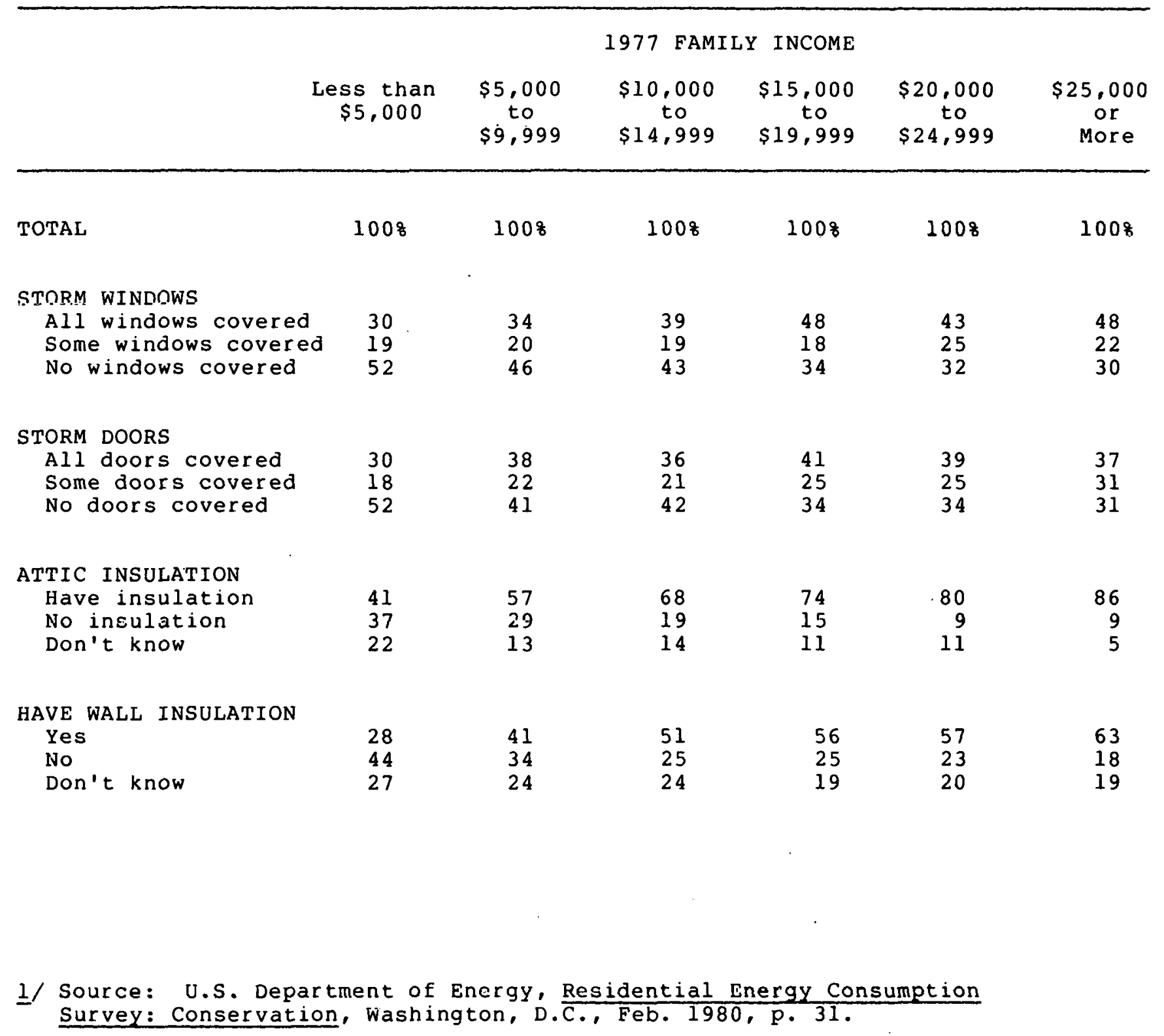


TABLE VII

CONSERVATION EFFORTS UNDERTAKEN IN 1978 BY 1977 FAMILY INCOME 1 / (Percentage of Households)

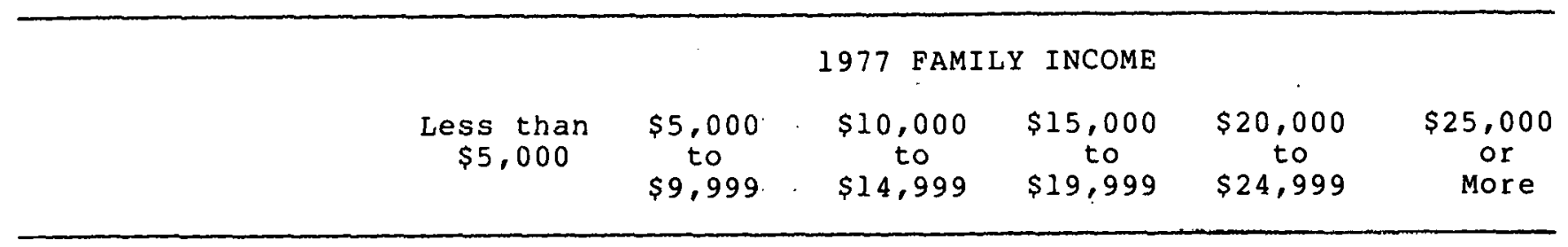

Type of Conservation

Measure:

ROOMS CLOSED OFF Yes 28

No 59

No answer

13

33

55

12

31
56

13

31

61

8

32

57

11

30

60

10

ADDED INEXPENSIVE

INSULATION

Yes

No

18

82

23

26

32

31

69

27

73

ADDED INEXPENSIVE EQUI PMENT

Yes

No

4
96

4
96

7

8

11

89

12

88

ADDED EXPENSIVE

INSULATION

Yes

INO

3
37

3
97

6
94

6
94

8

.92

91

ALUED EXP EISBIVE

EQUIPMENT

Yes

No

3
97

97

5
95

5
95

7
93

8

92

1/ Source: U.S. Department of Energy, Residential Energy Consumption Survey: Conservation, Washington, D.C., Feb. 1980, Pp: 31, 115. . 
the existing national weatherization program has been hampered by inadequate funding, excessive redtape and a general lack of emphasis and priority. Finally, the programs contained in the amendments to the Energy Production and Conservation Act, such as further expansion of the utility audit program and the establishment of an energy conservation loan bank, are aimed at middle-income families and do not provide sufficient incentives and assistance to families with incomes below $\$ 10,000$.

On the basis of these observations, FOMAC has proposed an energy assistance program design which, in itself, promotes conservation and in addition recommends an aggressive, comprehensive program to achieve conservation in low-income homes through education, weatherization and use of alternative sources of energy.

\section{B. Conservation Incentives}

The FOMAC program is designed to provide ongoing assistance while offering incentives and opportunities for conservation. A variety of conservation incentives are built directly into the method of providing assistance.

- Assistance will be provided only for needed energy.15/

- In almost all cases, the household will be required, on a monthly basis, to pay for energy beyond the subsidy amount. Conserving energy will reduce the amount which the household would pay.

- By utilizing conservation approaches which reduce energy usage below the established norm, the household is able to utilize its income for other necessity items, e.g. food.

15/ It was recognized that unusually severe weather as well as other factors will, at times, result in additional justified need. In these cases, an energy crisis intervention program similar to the one operated by the Community Services Administration should be utilized. FOMAC strongly recommends the continuation of a crisis intervention program at a \$100-150 million level. 
In addition, the overall program design calls for the inclusion of a broad range of energy conservation assistance. Such energy conserving measures as audits, weatherization, consumer education, and appropriate technology services to low-income households served by the energy fuel assistance program are integral elements of the total approach. A systematic approach to the energy problems and needs of low-income persons requires such integration of conservation services with the provision of assistance in paying for needed energy.

The local administering agency would be responsible for coordinating provisions of energy assistance with other local energy conservation programs. When clients are declared eligible for energy assistance, they would simultaneously be enrolled in a range of energy conservation programs. Energy audits would be implemented in homes in which assistance was provided. Whenever possible, weatherization would be performed in those households which receive assistance. Clients would be enrolled in conservation education programs. Such programs would provide information, skills and motivational techniques which would assist low-income households to implement conservation practices. Appropriate technology information would be shared and assistance would be provided to implement such alternatives. 
While it is recognized that the conservation incentives built into the overall program design result not only in energy savings but also expansion of the recipient's purchasing power (the "income effect" produced by any income transfer program), it is FOMAC's belief that the income effect produced by the program will be small enough so that there would be no possibility for the program to result in excessive use of energy.

This belief is based upon several factors:

1. There is ample evidence that the low-income household's present utilization of energy often is lower than is safe or healthy. There are many deaths each year attributed to inadequate home heating or cooling.

2. It is evident that the income elasticity for home energy over the relevant $r$ ange of income is low.

3. The proposed amount of the subsidy is not at levels that would produce substantial differences in the family's consumption habits for any commodity or service.

The net projection, therefore, is that this program may provide many low-income families the opportunity for the first time since 1972 to experience energy consumption at minimum humane levels -levels thought reasonable and proper for all other members of our society.

In summary, conservation is viewed as an integral part of the overall program and will be encouraged to the largest extent possible. Most importantly, the incentives for conservation are clearly related to the households' ability to have income 
available for other necessity items. Savings through conservation will accrue to the household and the net impact on increased energy use through provision of subsidy will be minimal.

Not only will the program design provide an incentive for conservation, but by making energy payment assistance part of a comprehensive energy conservation program, it assures that the poor will have both opportunities and incentives to conserve.

\section{The Benefits of Conservation}

Because the poor already consume energy at dangerously low levels, an effective conservation program requires more than education. Of paramount importance is a program to improve the housing stock which the poor inhabit. The benefits of conservation through weatherization can be viewed from hoth the individual and the societal level. In Table VIII FOMAC presents estimates of the role that conservation can play. The figures for 1979 through 1983 are based on a moderate increase in energy prices (23.38) and assume that the home of a low-income household had been weatherized as of January 1, 1979.

The proposed FOMAC assistance payments reflect actual losses in purchasing power due to increased energy prices. These levels of assistance would just offset the impact of such price increases. 
TABLE VIII

THE BENEFITS OF CONSERVATION

(current dollars)

Year Assistance Payments

Energy Conservation Net Savings on Fuel Bills $3 /$

\begin{tabular}{|c|c|c|c|c|c|}
\hline & $\mathrm{HEW} \underline{1 /}$ & FOMAC $\underline{2}$ & 308 & 408 & 508 \\
\hline 1979 & 164 & 262 & 140 & 187 & 234 \\
\hline 1980 & 203 & 324 & $1 \% 4$ & 232 & 290 \\
\hline 1981 & 251 & 400 & 215 & 286 & 358 \\
\hline 1982 & 310 & 495 & 265 & 354 & 442 \\
\hline 1983 & 383 & 611 & 328 & $\underline{437}$ & 547 \\
\hline TOTAL & 1311 & 2092 & 1122 & 1496 & 1871 \\
\hline
\end{tabular}

1/ Based on HEW Factsheet, President Carter's proposal for Low-Income Energy Assistance, Washington, D.C., September 12, 1979, and assuming moderate annual energy inflation rate after 1980.

2/. FOMAC payments approximately cover increases in energy prices.

3/ Conservation is calculated by assuming $2 / 3$ of energy bills are attributable to space conditioning. The 508 retrofit maximum is based on the office of Technology Assessment document titled Residential Energy Conservation, pp. 46-54, Washington, D.C. 1979 . 
Comparing these payments to a retrofit program that saves 508 of heating energy, weatherization alone would offset increased energy prices for a five year period. Further, the annual reduction in energy bills resulting from retrofit savings of 508 of energy consumption is considerably larger than the HEW assistance payments.

Two notes of caution should be sounded in making this comparison. First, weatherization alone will not meet the energy needs of low-income households. It will be necessary to couple weatherization with energy assistance payments. Second, if energy price increases persist for more than five years without being offset by $r$ ising income for the poor, the purchasing power of the low-income household will once again be quickly eroded.

Nevertheless, investment in weatherization constitutes a sound social and energy program. The weatherization of a building to conserve 508 of space conditioning energy costing $\$ 2,500$ (in 1980 dollars) could save roughly 55 million BTus per year, which is the equivalent of roughly 10 barrels of oil.16/ If the building stood for 20 years, a very conservative estimate, 1.1 billion BTUs or the equivalent of 200 barrels of oil would be saved. At these levels of savings weatherization is a cheaper source of energy than any available production approach.

16/ Office of Technology Assessment, Residential Energy Conservation, Washington, D.C., 1979, p.53. 
If FOMAC were to project this to a full scale national program, the contribution to the Nation's energy resources would be of considerable importance. Let us assume that $70 \%$ of the homes of low-income individuals can be weatherized to $40 \%$ conservation. In order to weatherize such homes over a ten year period, we would have to weatherize 1.1 million homes per year at an annual cost of $\$ 2.2$ billion (in 1980 dollars).17/ By the year 1990, weatherization of low-income homes would conserve roughly 240,000 barrels a day.18/ Over the 1 ife of these 11 million homes, almost 2 billion barrels of oil equi-. valent would be saved.19/

17/ In scaling down the savings from $50 \%$ maximum to an average of $40 \%$, one should also scale down the cost per unit from $\$ 2,500$ to $\$ 2,000$ although a perfect linear relationship may not hold.

18/ 11 million homes times 10 barrels per year, per home, divided by 365 days.

19/ 11 million homes times 20 years, times 10 barrels per year. 


\section{D: The Need for Utilization of Alternative Sources of Energy}

As noted above, the spiralling of energy prices will erode the benefits of weatherization. Thus weatherization serves as a sound, cost-effective, short-term defense against increased energy prices. A long-term approach to the problem of energy price increases requires that alternative sources of energy be utilized by all Americaus, including low-income individuals (because their purchasing power tends to lag behind others). Utilization of solar energy is critical. At today's prices, and given reasonable projections of future prices, a wide variety of solar energy options have become cost-justified. 20/

Economic analyses by the MITRE Corporation (1976), the Massachusetts Energy Policy Office (1976), Nadis (1977) and the Office of Technology Assessment (OTA 1978) all indicate that solar water and space heating are presently competitive with electric heating in many parts of the country and indy be competitive with oil and gas heating in the 1980's. 2ly

It should also be noted that weatherization and solarization are the most labor intensive of all potential sources of energy on a cost per unit energy basis. 22/ They generate jobs which cover

20/ The Consumer Energy Council of America, Energy Conservation in New Buildings: A Critique and Alternative Approach to the Department of Energy's Building Energy Performance Standards (Washington, D.C., April 1980), Chapter VII.

21/ A Report of the Union of Concerned Scientists, Energy Strategies: Toward a Solar Future, Ballinger publishing Company, Cambridge, Massachusetts, 1980, p. 125.

22/ Dr. Mark Cooper, Research Director, Consumer Energy Council of America, paper titled Energy Policy and Jobs, May 5, 1980. 
a broad range of occupations and levels of skill and are dispersed over a large geographical area. Thus, in addition to offering a fundamental solution to the problem of providing energy for the low-income population, they will have a positive, balanced economic effect.

\section{E. Recommendations for Conservation}

Given the need for and the major benefits to be obtained through comprehensive conservation, FOMAC recommends:

1. A massive expansion of the federal effort to weatherize the residential units of individuals receiving energy assistance payments. Considerable money and energy would be saved through such an expansion. Ten years is a reasonable goal in which to weatherize the residences of most low-income householis,

2. The development and implementation of a major consumer education program in energy conservation utilizing all forms of mass media and various sectors of society, i.e.. business, educational institutions, local government, churches, community groups, etc.

3. Coordination of the Departments of Housing and Urban Development and Agriculture's (Farmers Home Administration) low-income housing and community development programs with DOE's existing and pending programs in such areas as weatherization, consumer education, low interest loans, audits, energy standards programs for buildings, etc. Coordination of such efforts with the HHS and CSA's low-income programs is absolutely essential.

4. A significant expansion of alternative energy programs with a special emphasis on solar energy and technologies that are renewable, low cost, and labor intensive.

The above recommendations when coupled with an energy financial assistance program, would result in a comprehensive energy conservation service program for low-income households which would 
64

include weatherization of homes, conservation education, local energy planning and advocacy efforts, the use of alternative energy sources, where appropriate, and energy financial assistance payments. 


\section{PROGRAM FINANCING}

FOMAC, as a matter of record, still maintains its initial position regarding funding of low-income energy assistance.

After careful consideration, FOMAC rejected the following three options as being inequitable, legally and politically unsound, and incapable of generating the broad base of support necessary to ensure the program's success:

1. Utilizing the rebates from refiners to DOE resulting from prosecution of refiner overcharges.

2. Utilizing the crude oil import tariff.

3. Utilizing a crude oil equalization tax.

The following options were considered much more acceptable:

1. Direct funding from the Federal Treasury. (FOMAC felt this to be the most equitable option.)

2. Funding from the imposition of a value added, "Per-Btu" tax on all forms of energy.

3. Utilization of a portion of existing Federal gasoline tax. (It is probable that utilization of only 2 cents of the existing tax would yield full program funding.)

4. Utilization of the increased tax revenue which will result from decontrol.

It now appears that the program will be financed by the increased tax revenue resulting from the decontrol of crude oil. The projected higher prices for crude oil, due to decontrol, will be passed through to refined petroleum products, including home 
66

heating oil. Significantly, a portion of the revenue from the Windfall profits Tax will be used to provide assistance : to all low-income consumers, not just heating oil consumers.

To the extent that heating oil prices have been rising faster than other fuels -- although that will undoubtedly change as a result of national policy (ie., equating natural gas prices with foreign oil) -- it is important that the added burden faced by the low-income home heating oil consumer due to decontrol be offset to the maximum extent possible by the amount of energy assistance which the consumer receives. 
Summary of various energy assistance legislative proposals submitted to the U.S. House of Representatives and U.S. Senate:

\section{HOUSE BILLS}

H.R. 321 -- By Rep. Hamilton Fish (D-NY): "Energy Stamp Assistance Act of $1979 "$

H.R. 762 -- By Rep. Louis Stokes (D-OH): "Federal Utility and Energy Low-Income Subsidy Act of 1979"

H.R. 3919 -- By Rep. Al Ullman (D-OR): "The Crude Oil Windfall Profit Tax Act"

H.R. 4799 -- By Rep. Thomas J. Downey (D-NY): "Basic Fuel Assistance Act of 1979" (Same as S. 1270, Senator Javits' bill)

H.R. $5039--$ By Rep. Martin Olav Sabo (D-MN): "Fuel Stamp Act of $1979 "$

H.R. 5237 -- By Rep. Peter. A. Peyser (D-NY)

H,R. 5241 -- RY Rep. Toby Moffctt (D-CT) and Rép. Janes M. Snannon (D-MA): "Fuel Assistance Act of 1979"

H.R. 5256 -- By Rep. Frederick W. Richmond (D-NY)

H.R. 5318 -- By Rep. Lawrence Coughlin (R-PA) H.R. 5552 -- By Rep. Paul Simon (D-IL): "Home Energy Assistance
Act"

H.R. 5678 -- By Rep. Matthew F. McHugh (D-CT) 
S. 771 -- By Sen. Lowell Weicker, Jr. (R-CT): "Energy Stamp Act of $1979^{\prime \prime}$

S. 1270 -- By Sen. Jacob Javits (R-NY) and Sen. Henry M. Jackson (D-WA): "Basic Fuel Assistance Act of 1979"

S. 1331 -- By Sen. Joseph R. Biden, Jr. (D-DL): "Emergency Fuel Assistance Act of 1979"

S. 1603 -- By Sen. Charles MCC. Mathias (R-MD) and Sen. Howard H. Baker (R-TN): "Home Heating Stamp Act of 1979"

S. 1633 -- By Sen. John Heinz (R-PA): "Fuel Cost Assistance Act for the Elderly and Handicapped"

S. 1664 - By Sen. Abraham Ribicoff (D-CT)

S, 1724 -- By Sen. Harrison A. Williams (D-NJ), Sen. Edward M. Kennedy (L-MA), Sen. Jacul Javils (R-NY), Sen. llowara $M$. Melzeniarum (D-OII), and Ecn. John Durkin ( $D=N H)$ : "Home Finergy Assistance Act"

S. 1725 -- By Sen. Gaylord Nelson (D-WI), Sen. Edward M. Kennedy (D-MA), and Sen. Donald W. Riegle, Jr. (D-MI): "Economic Opportunity Amendments of 1979"

S. 1766 -- By Sen. Daniel P. Moynihan (D-NY)

S. 2723 -- By Sen. Daniel P. Moynihan (D-NY): "Low-Income Energy Assistance Act of $1980^{\prime \prime}$ 


\section{SYNOPSIS OF LEGISLATIVE ACTION*}

P.L. 96-216 (H.R. 4930)

In addition to providing FY 80 Department appropriations, amended to include $\$ 1.35$ billion in funding for low-income energy assistance programs during the $1979 / 1980$ winter. When coupled with a regular appropriation of $\$ 250 \mathrm{milli}$ ion for this purpose, provides a total of $\$ 1.6$ billion for low-income energy assistance in FY 80. Amended on Senate floor October 16, 1979, to provide $\$ 1.2$ billion. In conference, November 7, 1979, the sum of $\$ 1.35$ billion was decided upon. Conference agreement passed House and Senate November 9, 1979. The House had earlier approved $\mathrm{H}$. J. Res. 430 , providing $\$ 1.35$ billion for low-income energy assistance. Enacted into law November $27,1979$.

H.R. 321 (Fish)

Energy Stamp Assistance Act. Provides energy stamps valued at between $\$ 25$ and $\$ 50$ monthly for purchase of home energy products, or to pay a portion of monthly rent where fuel bills are not paid directly. Makes eligible households with annual gross incomes below $\$ 12,500$. Introduced January 15, 1979; referred to Committee on Interstate and Foreign Commerce.

H.R. 762 (Stokes)

Proposes a Federal Utility and Energy Low-Income Subsidy Program that would provide assistance to recipients of food stamps, AFDC and SSI, along with those with incomcs below $200 z$ of the "poverty levels." provides benefits through bill reductions of varying percentages, with suppliers reimbursed for the cost of any reductions by the Federal Government. Provides benefits applicable to most home energy and utility costs. Introduced January 15 , 1979; referred to Committee on Interstate and Foreign Commerce.

H.R. 3919 (Ullman)

The Crude Oil Windfall profit Tax Act. As amended in the Senate, and in conference, provides for a Home Energy Assistance program. The Home Energy Assistance Act (S. 1724) was amended and added to H.R. 3919 on the Senate floor, as a substitute for the lowincome energy assistance provisions in H.R. 3919 reported by the Senate Finance Committee. Introduced May 3, 1979; referred to Committee on Ways and Means. Reported, amended, June 22 (H. Rept. 96-304). Passed House, amended, June 28, 1979, referred in Senate to Committee on Finance July 10, 1979. Reported, amended Nov. 1, 1979 (S. Rept. 96-394). Passed Senate, amended, December 17, 1979. Conference agreement reached February 26, 1980 (H. Rept. 96-817).

*Source, Library of Congress, Congressional Research Service, Energy Assistance for Low-Income Houseuholds, Issue Brief No. IB 80024, Richardson, Joe, March 1980 and other references. 
H.R. 4799 (Downey)

Proposed a basic fuel assistance program, with benefits provided through home energy suppliers, similar to that proposed in S. 1270. Introduced July 16, 1979; referred to more than one committee.

H.R. 5039 (Sabo)

Proposes a fuel stamp program to provide assistance to food stamp recipients, for the period December through March of each year." Provides that eligible households would receive, in fuel stamps, a monthly equivalent of their food stamp allotment, except that the minimum benefit would be $\$ 20$ month and the maximum would be $\$ 50$. Proposes that stamps could be used to pay directly for home heating fuels or to pay a portion of rent. Introduced July 31, 1979; referred to more than one committee.

H.R. 2237 (Peyser)

Proposes a fuel stamp program to provide assistance to recipients of food stamps, for the period December through March of each year. Provides that eligible households would receive, in fuel stamps, a monthly amount equivalent to their fuel costs, up to a maximum of $\$ 75$ a month. Proposes that fuel stamps could be used to pay directly for home heating fuels or to pay a portion of rent. Introduced September 11, 1979; referred to more than one committee.

H.R. 5241 (Shannon, Moffett)

Establishes a fuel assistance program for households with incomes less than $125 \%$ of the "Poverty levels" (up to 150 \% for elderly households) and SSI households. Also provides for a MiddleIncome Energy Tax Credit. Proposes that fuel assistance benefits would be provided through home energy suppliers (reduced bille) as proposed in S. 1270 and H.R. 4799, axcept that benefits would be capped at $\$ 30$ a month, and would be limited to states where weather patterns, energy costs, and other factors indicate a program is warranted. Introduced September 11, 1979; referred to more than one committee.

H.R. 5265 (Richmond, et al.)

Proposes to increase food stamp monthly allotments during the heating season by the degree to which fuel oil prices have risen. Would be operative in colder states only. Introduced September 13, 1979; referred to Committee on Agriculture. 
H.R. 5318 (Coughlin)

Provides for a tax credit for home heating oil expenses. Introduced september 18, 1979; referred to Committee on Ways and Means.

H.R. 5552 (Simon)

Home Energy Assistance Act. Identical to S. 1724, as originally introduced in the Senate. Establishes a program of block grants to States to operate state-designed programs of low-income home energy assistance, under general Federal guidelines. Introduced October 11, 1979, referred to Committee on Interstate and Foreign Commerce.

H.R. 5678 (McHugh)

Home Energy Tax Relief Act. Provides a tax credit for lowand middle-income taxpayers for amounts paid for primary fuels used in their principal residences. Establishes a program under which the Treasury will make advance payments of such credit to fuel suppliers. Introduced october 23, 1979; referred to more than one committee.

H.J. Res. 427 (Natcher)

See H.J. Res. 430 .

H.J.Res. 430 (Natcher)

Provides for urgent supplemental appropriations for low-income energy assistance during the winter of $1979 / 1980$. Appropriates $\$ 1.35$ billion. Introduced October 23,$1979 ;$ referred to Committee on Appropriations. Reported October 24, 1979 (H. Rept. 96-552, Pts. 1 and 21. Passed House, amended, October 25, 1979. This appropriation was incorporated in P.L. 96-126.

\section{S. 722 (Durkin)}

Provides for refundable tax credits for home heating oil expenditures, including a credit for renters. Limits credit to $\$ 200$ and extends eligibility to incomes of $\$ 35,000$. Introduced March 21, 1979; referred to Committee on Finance. 
S. 771 (Weicker)

Energy Stamp Act of 1979. Establishes an Energy Stamp Program, patterned after the Food stamp Program, to be administered through the Community Services Administration and local community action agencies. Benefits and, to some extent, eligibility to be determined locally. Recipients to pay one-third of the value of any stamps received. Authorizes appropriations of $\$ 100$ million annually. Introduced March 27, 1979; referred to Committee on Labor and Human Resources. Provisions of measure incorporated into S. 1724 ordered to be reported October 19, 1979.

S. 1270 (Javits, Jackson)

Basic Fuel Assistance Act of 1979. Establishes a program of assistance for households eligible for SSI, $\triangle F D C$, or food stamps and continues crises intervantion programa. provides benefits in the form of reduced bills for primary residential energy sources, with suppliers paid the cost of reduced bills. Requires recipient households to pay a proportion of their income; the program would pay the remainder of the bill. Caps benefits at $\$ 45$ per household per month in the first year; in later years HEW would set benefit ceilings. Provides openended appropriations for the basic benefit program; authorizes $\$ 40$ million annually for $c r$ isis intervention activities. Introduced June 4, 1979; referred to Committee on Labor and Human Resources. Provisions of measure incorporated into S. 1724 ordered to be reported October 19, 1979.

S. 1331 (Biden)

Emergency Fuel Assistance Act of 1979. Authorizes a fuel stamp program for elderly households in areas found to have an "energy emergency." Provides that Federal Emergency Management Administration would administer the program through state Welfare offices. Authorizes annual appropriations of $\$ 150$ million. Introduced June 13, 1979; referred to Committee on Labor and Human Resources. Provisions of measure incorporated into S. 1724 ordered to be reported October 19, 1979.'

S. 1603 (Mathias, Baker)

Home-Heating stamp Act of 1979. Establishes a home-heating stamp program patterned after the Food stamp program. Makes food stamp households eligible for home-heating stamp allotments during a 
S. 1603 (Mathias, Baker) continued

state's heating season. Stipulates that food stamp households must pay a percentage of income to the issuing agency in order to receive an allotment. Provides that the Department of Agriculture, operating the program in conjunction with food stamps, could waive the requirement to purchase allotments. Provides that allotments be adequate for minimum heating needs. Provides for open-ended appropriations. Introduced July 31, 1979; referred to Committee on Labor and Human Resources. Provisions of measure incorporated into S. 1724 order to be reported October 19, 1979.

S. 1633 (Heinz)

As revised during consideration in the Senate Finance Committee, provides that suppliers of home heating energy would be eligible for a refundable tax credit equal to the revenue foregone in reducing home heating costs to low-income households. Incorporated as State option in S. 1724. Introduced August 2, 1979.

S. 1664 (Ribicoff, et al.)

Provides for a tax credit for residential heating oil expenditures. Similar provisions included in Senate version of $H \cdot R$. 3919. Introduced August 2, 1979, referred to Committee on Finance.

S. 1724 (Williams) (Incorporated in H.R. 3919)

Home Energy Assistance Act. Establishes a program of block grants to States to operate State-designed programs of lowincome home energy assistance, under general Federal guidelines. Authorizes $\$ 3.025$ billion in FY 81 , and $\$ 4.025$ billion in FY 82 and FY 83. Similar provisions included in S. 1725. Reported from the Labor and Human Resources Committee October 25, 1979. Amended version incorporated in H.R. 3919 November. 15, 1979.

S. 1766 (Moynihan)

Energy Cost Assistance Act. Provides for standard cash payments for AFDC and SSI households in the form of grants to states (for AFDC recipients) and standard add-ons to Federal SSI checks. Provides that standard payment would be $\$ 200$ annually, adjusted in later years by the extent to which home heating price increases exceed the general inflation rate. Also includes tax credits for home heating expenditures similar to provisions included in Senate version of H.R. 3919. Introduced September 19, 1979; referred to Committee on Finance. 
S. 2723 (Moynihan)

Low-Income Energy Assistance Act of 1980. Amends the Social Security Act to provide for low-income energy assistance to recipients of AFDC and SSI. Section 102 of Public Law 96-223, the Crude Oil Windfall Profit Tax Act of 1980 specifies that 258 of the net revenues from that tax will be allocated for low-income assistance. This amount is to be divided equally between a program of assistance for AFDC and SSI recipients under the Social security Act and a program of emergency energy assistance. S. 2723 attempts to meet the first half of section 1-2, P.L. 96-223 through a Block grant program. This legislation would establish a program for fiscal years 1982-90. 
Baroni; Fr Geno, Assistant Secretary of Hud for Neighborhoods, Voluntary Ásociationș, and Consumèr Protection, Energy and Urban Policies/Programs; DOÉ Office of Consumer Affairs, Washington, D.C?, 1978:

Barth, Michael; C.; Mills, Gregory; and Seagrave, Charles. The Impact of Rising Energy prices on the Low-Income Population: An Analysis of the Home-Heating Problem and Policy Alternatives. Technical Analysis Paper 3. Office of the Assistant Secretary for Planning and Evaluation, Department of Health, Education, and Welfare, Washington, D.C., March 1975.

Bloom, Martin, et al. The Effect of Rising Energy Prices on the Low and Moderate Income Elderly. Federal Energy Administration, Washington, D.C., March 1975.

Bossong, Ken. Citizen's Energy Project of the Center for science in the Public Interest, selections from Local Energy Action Program Survey. Washington, D.C., September 1977.

Brannon, Gerald $M$. The Income Distribution tffects of Energy Policy, Ford Foundation Energy Policy Project Report: Energy Taxes and Subsidies, Washington, D.C., 1974.

Brazzel, Hewlett, et al., A distributional Analysis of the 1985 Energy Projections for The Annual Report to Congress of the Energy Information Administration. Analysis Memorandum AM/IA/78-09, Department of Energy, Washington, D.C., June 1978 .

Bureau of Census, U.S., Washington, D.C.

Current Population Reports, Series P-60, March 1979;

Current Population Reports, March 1980.

Community Services Administration, U.S., Washington, D.C. Save Energy: Save Money, May 1977;

Still Coping with the Energy Crisis, September 1979;

Community Planning for Home Heating Emergencies, prepared by Design Alternatives, Inc., October 1979;

No More Heat? A Self-Help Booklet, prepared by Design Alternatives, Inc., October 1979; 
Poor and without Heat: National Overview of Price and Supply-Related Problems with Home Heating Sources Used by Low-Income People, prepared by Design Alternatives, Inc., October 1979;

A Dealer Tax Credit, Income Indexed Fuel Payment Assistance Program, memo, Richard Saul, Chief, CSA Energy Program to C. Anthony Jackson, Director, CSA Office of Program Development, January 24, 1980;

Optimizing Weatherization Investments in Low-Income Housing; Economic Guidelines and Forecasts, prepared by the National Bureau of Standards, February 1980 ;

Consumer Energy Council of America, Energy Conservation in New Buildings: A Critique and Alternative Approach to the Department of Energy's Building Energy Performance Standards, Washington, D.C., April 1980.

Cooper, Mark, paper, Energy Policy and Jobs, Consumer Energy Council of America, May 1980 .

Department of Labor, U.S. Bureau of Labor Statistics, Consumer Expenditure Survey: Integrated Diary and Interview Survey Data: Bulletin No. 1992, Washington, D.C., 1978;

Department of Energy, U.S., Washington, D.C.;

Transcript, Case \#DEH-00581, DOE Office of Hearings and Appeals, August 1978;

Low-Income Energy Assistance: A Profile of Need and Policy Options, prepared by the Fuel Oil Marketing Advisory Committee to DOE, July 1979;

Alternative Metering Practices: Implications for Conservatiul in Multi-Family Residences, July 1979;

Single-Family Households: Fuel oil Inventories and Expenditures, National Interim Energy Consumption Survey, prepared by the Energy Information Administration, December 1979;

Residential Energy Consumption Survey: Conservation, prepared by the Energy Information Administration, February 1980.

Energy Consumption by Low-Income Households. A Review of Studies, Surveys and Models, prepared by the ICF Incorporated, April 1980; 
Department of Health and Human Services (formerly HEW), U.S., Washington, D.C.

Memo: President Carter's Proposal for Low-Income Energy Assistance, September 12, 1979;

Statement of John L. Palmer, Deputy Assistant Secretary of HEW for Planning and Evaluation before the Special Committee on Aging, U.S. Senate, September 13, 1979;

Testimony of Patricia Roberts Harris, Secretary of HEW before the Subcommittee on Labor - HEW of the Committee on Appropriations of the U.S. House of Representatives, October 18, 1979;

Testimiony of Stanford G. Ross, Commissioner, Social Security Administration, HEW, before the Subcommittee on Labor-HEW of the Committee on Appropriations of

the U.S. House of Representatives, October 18, 1979;

Low-Income Energy Assistance Program, HHS, Federal Register, Vol. 45, No. 106, May 30, 1980.

Eisenberg, Joel, New England Econcomic Research Office, The Impact of Recent Oil Price Increases on Low-Income Heating Oil Users, memo to the New England Congressional Caucus, Washington, D.C., Notober 11, 1979;

Frankena, Frederick, Energy and the Poor: An Annotated Bibliography of Social Research, Exchange Bibliograph 1307, Council of Planning Librarians, Monticello, Illinois, July 1977.

Goedert, Jeanne E. and Goodman, Jack L., Jr., Paper 249-2, Indicators of the Quality of U.S. Housing. The Urban Institute, Washington, D.C., September 1977.

Grier, Eunice and George, Bethesda, Maryland

High Fuel Oil Sales: The Impact on Low-Income Households. A report to the Community Services Administration, August 1978;

The New England Energy Consumer, January 1979;

Too Cold - - Too Dark, Rising Energy Prices and Low-Income Households, A report to the Community Services Administration, April 1980 .

No Cheap Fuel Anymore, Results of the CSA-NCAAEDA (National Community Action Association Executive Directors' Association) survey of Energy Prices, A Report to the Community Services Administration, May 1980 . 
Herendeen, Robert A, Affluence and Energy Demand, Mechanical Engineering, October $1 \overline{974}$.

Herendeen, Robert A. and Tanaka, Jerry, Energy Cost of Living. Document 171. Center for Advanced Computation, University of Illinois, 1975 .

Kelley, Tom, Ford Foundation Energy Policy project Reports: The American Energy Consumer. The Ford Foundation, washington, D.C., 1975.

Kindall, Henry $W$. and Nadis J. Steven, Energy Strategies: Toward a Solar Future, A Report of the Union of Concerned Scientists, Dallinger Publishing Co., Cambridge, Massachusetts, 1980 .

National Center for Appropriate Technology, Energy and the Poor: An Imperative for Action, Butte, Montana, December 1979.

National Consumer Law Center, Washington, D.C.;

Low-Income weatherization Program: Suggested Comments on

the New Interim Regulations, Energy Bulletin, No. 12, Apri1 15, 1980;

Regulations Implementing Next Year's Low-Income Energy Assistance Program, Energy Bulletin, No. 14, June 10, 1980 .

National Energy Plan, Executive Office of the President, Energy Policy and Planning, April 29, 1977.

Newman, Dorothy K., and Day, Dawn (eds.). Furd Fuundation Dnergy Policy Project Reports: The American Energy Consumer. The Ford Foundation, Washington, D.C., 1975.

Office of Technology Assessment, U.S. Congress, Residential Energy Conservation, Washington, D.C., 1979 .

Ohio Energy Credits Advisory Committee, Energy Assistance Programs and Pricing Policies in the 50 states to Benefit the Elderly, Disabled or Low-Income Households, The Institute of Urban Studies, College of Urban Affairs, Cleveland State University, Cleveland, Ohio, 1979.

Palmer, John L., Todd, John E.; and Tuckman, Howard F, The Distributional. Impact of Higher Energy Prices: How Should the Federal Government Respond, Public Policy 24, Fall 1976.

Perlman, Robert, and Warren, Roland L., Families in the Energy Crisis: Impacts and Implications for Theory and Policy, Brandeis University, Waltham, Massachusetts, 1977. 
Richardson, Joe, Energy Assistance for Low-Income Households, Issue Brief No. I B80024, Congressional Research Services, Library of Congress, Washington, D.C., March 1980.

Schenider, Alvin, Blacks, Cities, and the Energy Crisis, Urban Affairs Quarterly, Vol. 10, No. l, Syracuse University, September 1974 .

Schlesinger, James, Secretary of Energy, Energy and Urban Policies/Program, DOE Office of Consumer Affairs, Washington, D.C., 1978 .

Social Development Commission of Milwaukee County, Preliminary Report on the 1979-80 Federal Energy Crisis Assistance Program, a statistical report to Anthony Maggiore from Dorothy Brown and Marilyn Mueller, Milwaukee, Wisconsin, May 5, 1980.

Stobaugh, Robert and Yergin, Daniel, The Energy Outlook: Combining the Options, Harvard Business Review, JanuaryFebruary 1980 .

Struyck, Raymond $J$, The Housing Situation of Elderly Americans. Paper 0001-3. Washington, D.C., The Urban Institute, November 1976.

Urban Institute, The Distribution of Home Energy Expenditures by American Households in 1976-77: An Analysis of Energy Need Among Low-Income Groups, Washington, D.C., May 1979 .

U.S. Consumer Product Safety Commission, Washington, D.C., Residential Electrical Wiring Systems and Thermal Insulation, August 1979.

U.S. Senate, Committee on Aging, The Impact of Rising Energy Costs on Older Americans, Part I, II, September 24-25, 1974.

Washington Center for Metropolitan Studies, National Survey of Household Energy Use, Washington, D.C., 1975;

Colder...Darker: The Energy Crisis and Low-Income Americans An Analysis of Impact and Options, a report to the Community - Services Administration, 1977.

Let Them Freeze in.the Dark, a report prepared for the Community Services Administration, Grier Partnership, 1974 .

National Survey of Household Energy, Grier Partnership, 1975 . 


\section{FUEL OIL MARKETING ADVISORY COMMITTEE}

CHAIRPERSON :

John G. Buckley

Vice President

Northeast Petroleum Industries

295 Eastern Avenue

Chelsea, Massachusetts 02150

(617) 884-7570

\section{MEMBERS}

Joseph R. Albers

Este Oils Company

5556 Vine Street

Cincinnati, Ohio 45217

(513) 242-5300

Ellen Berman

Executive Director

Consumer Energy Council

of America

1990 M Street, N.W. - \#620

Washington, D.C. 20036

(202) 659-0404

Vern Birrenkott

Birrenkott Oil Company

Rural Route

Lemmon, South Dakota 57638

(605) 374-3612

\section{Sid Berson}

Energy Unlimited, Inc.

50 Harvard Street

New Britain, Connecticut 06051 (203) 223-2717

Charles Burkhardt

Executive Vice President

New England Fuel Institute

20 Summer Street - Box 888

Watertown, Massachusetts 02172

(617) $924 \div 1000$
Bruce Carpenter

Vice President

Energy Cooperatives, Inc. (ECI)

6300 River Road

Rosemont, Illinois 60018

(312) 692-6800, ext. 326

Charles J. Cicchetti, Ph.D.

University of Wisconsin

Department of Economics

6406 Social Science Building

Madison, Wisconsin 53706

(608) 266-1242

Allan Davis

Boasberg, Hewes, Klores,

Feldesman \& Tucker

2101 L Street, N.W.

Washington, D.C. 20036

(202) 466-8960

Robert DeBlois

DeBlois Oil Company

Colfax street

Pawtucket, Rhode Island 02860 .

(401) 722-8000

Mary Ann Donnatto

Utility Coordinator

Public Service Department

City of Houston

P.O. Box 1562

Houston, Texas 77001

(713) 222-3910 
Robert W. Fawcett

Fawcett Services, Inc.

Tyler Court

Cambridge, Massachusetts 02140

(617) 547-2360

Rod Flannery

Flannery Oil Company

318 East Main Street

Wessington Springs, South Dakota

(605) 539-1300

57382

E. J . Fourticq

President and Chief Executive officer

United Petroleum

The Fairmount Building

333 West Loop North, Suite 304

Houston, Texas 77024

(713) 688-9000

Robert B. Greenes

Public Fuel Service

357 East 116 th Street

New York, New York 10029

(212) 722-3000

Ken Guscott

Ken Guscott and Associates

Prudential Center

Boston, Massachusetts 02199

(617) 267-9260

Linneal Henderson

Howard University

School of Business and

Public Administration

2345 Sherman Avenue, N.W.

Washington, D.C. 20059

(202) 636-7433

Charles Jacobus

Quick Flash Fuel Company

$700 \mathrm{~W}$. State Street

Milwaukee, Wisconsin 53213

(414) 258-7700
Henry Lee

Research Program Coordinator

for Energy and Environmental

Policy Center

79 Boylston Street

Cambridge, Massachusetts 02138

(617) 495-1350

Eugene Lobe

County Commissioner

Kitsap County Court House

614 Division Street

Port Orchard, Washington 98366

(206) 876-7121

Tony Maggiore

Associate Director

Community Relation and social

Development Commission

161 West Wisconsin Avenue

Milwaukee, Wisconsin 53203

(414) 272-5600

Larry Martinez

Deputy Director

Community Affairs Division

Office of the Governor

ROOM 104

PERA Building

P.O. Box 5334

Sante Fe, New Mexico 87503

(505) 827-2205

Robert P. McGinley

The SICO Company

$15 \mathrm{Mt}$. Joy Street

Mt. Joy, Pennsylvania 17552

(717) 653-1411

Dean H. Prosser

General Manager

Products and Pricing

Amoco

200 East Randolph

Chicago, Illinois 60601

(312) 856-5111 
Louis G. Reames

-Camden Gas and Oil, Inc.

Camden, South Carolina 29020

(803) 432-6106

George Romanoff

Cascade Fuel Oil Co., Inc.

17414 th Avenue South

Seattle, Washington 98134

(206) 622-6050

Robert W. Schrimpf

Piasa Motor Fuel

P.O. Box 484

Alton, Illinois 62002

(618) 254-7341

Jake J. Simmons

Amerada Hess Corporation

1185 Avenue of the Americas

New York, New York 10036

(201) 636-3000

Edward Smolarski

Vice President

The Oil Shale Corporation (TOSCO)

10100 Santa Monica Boulevard

Los Angeles, California 90067

(213) 552-7000

E. Shirley Thomas

188 Elmwynd Drive

Orange, New Jersey 07050

(201) 733-8579

Ron Vails

President

CR Systems

25 S. Bemiston

Suite 8

Clayton, Missouri 63105

(314) 727-7934

John B. Wade

The Fairlie \& Wilson Company

533 South 5 th Street

Elizabeth, New Jersey 07296

(201) 248-3300
Maxine Waters

State Assemblywoman

California Legislature

7900 South Central Avenue

Los Angeles, California 90001 (213) 582-7371

Christian M. Weber, Jr.

President

Federal Oil Company

Federal Street and River Road

Camden, New Jersey 08103

(609) 829-1100

Byron S. Weil

oils, Inc.

300 West Washington street

Chicago, Illinois 60606

(312) 726-9606

Larry Young

State Legislator (Maryland)

Director, Joint Center for

Urban Environmental Studies 101214 th street, N.W.

Suite 906

Washington, D.C. 20005

(202) 347-6020 


\section{Department of Energy \\ Washington, D.C. 20585}

United Sta

DOE 350

THIRD CLASS MAIL 